\title{
Catalog of medium and large-sized mammals from the state of Pará, Brazil, housed in the Museu de Zoologia da Universidade de São Paulo (MZUSP) \\ Catálogo de médios e grandes mamíferos do estado do Pará, Brasil, depositados no Museu de Zoologia da Universidade de São Paulo (MZUSP)
}

\author{
Fabio Oliveira do Nascimentol (1) | Rafaela Lumi Vendramel, "I (1) \\ Museu de Zoologia da Universidade de São Paulo. Mastozoologia. São Paulo, São Paulo, Brasil \\ "Museu de Zoologia da Universidade de São Paulo. Programa de Pós-Graduação em Sistemática, Taxonomia Animal e Biodiversidade. \\ São Paulo, São Paulo, Brasil
}

\begin{abstract}
The Mammal Collection of the Museu de Zoologia da Universidade de São Paulo (MZUSP) is one of the largest collections of Neotropical mammals in Latin America, housing about 50,000 specimens. One of the most representative series in this collection comes from the Brazilian Amazon Biome. Among the Brazilian Amazon states, Pará was target of several scientific expeditions led by MZUSP researchers, becoming one of the most representative in terms of number of specimens and species richness in the collection. Here we present a list of the medium and large-sized mammal specimens from Pará state housed in the MZUSP, with comments about taxonomy, the conservation status of the species and other associated information. We found 1,910 specimens representing 79 species and nine orders of medium and large-sized mammals from Pará. Among these, 24 species are currently classified as threatened in Brazil. Furthermore, we found some areas with higher concentration of collection localities, such as at the banks of the lower Rio Tapajós and in the northeastern region of the state. The present catalog plays an important role in presenting the currently known biodiversity of medium and largesized mammals of Pará, also acting as a primary source for systematics, ecological, conservation and biogeographic studies.
\end{abstract}

Keywords: Amazon. List of specimens. Mammalogy. Scientific collection.

Resumo: A Coleção de Mamíferos do Museu de Zoologia da Universidade de São Paulo (MZUSP) é uma das maiores coleções de mamíferos neotropicais da América Latina, abrigando cerca de 50.000 espécimes. Uma de suas séries mais representativas é proveniente da Amazônia brasileira. Entre os estados amazônicos brasileiros, o Pará foi alvo de inúmeras expedições científicas conduzidas por pesquisadores do MZUSP, tornando-se um dos mais representativos em termos de quantidade de espécimes e riqueza de espécies na coleção. Aqui, apresentamos uma lista de mamíferos de médio e grande porte do Pará depositados no MZUSP, com comentários sobre taxonomia, estado de conservação da espécie e outras informações associadas. Listamos 1.910 espécimes, representando 79 espécies e nove ordens de mamíferos de médio e grande porte do Pará. Entre estes, 24 espécies estão atualmente ameaçadas no Brasil. Além disso, observamos algumas áreas com maior concentração de coletas, tais como as próximas às margens do baixo rio Tapajós e na região nordeste do estado. O presente catálogo desempenha papel importante em apresentar a biodiversidade atualmente conhecida de mamíferos de médio e grande porte do Pará, também atuando como uma fonte primária para estudos sistemáticos, ecológicos, conservacionistas e biogeográficos.

Palavras-chave: Amazônia. Lista de espécimes. Mastozoologia. Coleção científica.

NASCIMENTO, F. O. \& R. L. VENDRAMEL, 2020. Catalog of medium and large-sized mammals from the state of Pará, Brazil, housed in the Museu de Zoologia da Universidade de São Paulo (MZUSP). Boletim do Museu Paraense Emílio Goeldi. Ciências Naturais 15(3): 863-903. DOI: http://doi.org/10.46357/bcnaturais.v15i3.240.

Autor para correspondência: Fabio Oliveira do Nascimento. Museu de Zoologia da Universidade de São Paulo. Mastozoologia. Avenida Nazaré, 481 - Ipiranga. São Paulo, SP, Brasil. CEP 04263-000 (fabnasc@gmail.com).

Recebido em 19/12/2019

Aprovado em 23/10/2020

Responsabilidade editorial: Alexandra Maria Ramos Bezerra
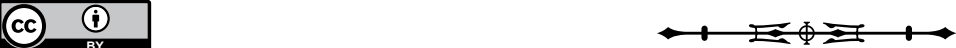


\section{INTRODUCTION}

The Mammal Collection of the Museu de Zoologia da Universidade de São Paulo (MZUSP) currently houses about 50,000 specimens preserved as dry skins, skulls and postcranial skeletons, and in liquid, including whole specimens in alcohol. This collection is one of the largest collections of Neotropical mammals in Brazil and Latin America (de Vivo et al., 2011; Bezerra, 2012). The MZUSP does not have concentrated sampling in certain Brazilian regions or biomes but has a broad geographic coverage that includes every biome and most Brazilian states (Percequillo, 2005). One of the most representative series in MZUSP comes from the Brazilian Amazon biome. Since its beginning in the late nineteenth and early twentieth centuries, the MZUSP has sent professional specimen collectors to the Amazon (Pinto, O., 1945).

Among the Brazilian states that encompass the Amazon, Pará is one of the most representative in number of specimens housed in MZUSP. Located in northern Brazil, the Pará state is the second-largest federal unity of the country, with an area of $1,245,759 \mathrm{~km}^{2}$, representing 14\% of the Brazilian territory (IBGE, 2018). This state encompasses five areas of endemism: Belém, Guiana, Rondônia, Tapajós, and Xingu (Silva, S. et al., 2019, fig. 1). The predominant vegetation is composed of ombrophilous forest, with areas of dense and open forests, and transitional areas with the Cerrado in the southern region of the state (IBGE, 2004). According to Köppen's classification, the climate of Pará state is mainly monsoonal and some areas do not have a dry season (Alvarez et al., 2013).

Localities within Pará were explored by several MZUSP scientific expeditions. The region was explored by Ernst Garbe (in the early 1920s), Alonso Olalla (in the 1930s and 1940s), and the "Expedição Permanente à Amazônia” project (EPA; 1967-1987), coordinated by Paulo Emílio Vanzolini (Pinto, O., 1945; Rodrigues et al., 2000). Contrastingly, in the first two decades of the 21st century, much of the mammal material from Pará state was not derived from collection expeditions aimed to increase the collection, but rather from environmental impact studies for large enterprises such as railways, highways, mining, and hydroelectric power plants (J. Gualda-Barros, personal communication). In such cases, there is a bias towards the collection of small mammals, especially rodents, bats, and marsupials. In environmental impact studies, the collection of medium and large-sized mammals is mostly occasional, derived from dead individuals found in the wild or roadkilled (F. O. Nascimento, personal observation).

Due to the large collection expeditions carried out in the last century, and few other occasional contributions, the MZUSP is one of the most representative collections in terms of the number of specimens and species from Pará. Here, we present a complete list of the medium and large-sized mammal specimens from Pará state housed in the MZUSP, commenting about the taxonomy, conservation status of the species and other noteworthy associated information.

\section{MATERIAL AND METHODS}

We surveyed and listed all specimens from Pará state, Brazil, housed in the MZUSP, including both wild and domestic species. For each specimen, we catalog the preserved parts such as skin, skull and/or skeleton. We transcribed the information on the species name, collection locality and sex present on the specimens labels as well as the handwritten, typed and digitized specimens catalogs held in the MZUSP. Furthermore, we reidentified all specimens.

We consider species belonging to the orders Cingulata, Pilosa, Sirenia, Carnivora, Artiodactyla, Perissodactyla, and Primates as medium and large-sized mammals, as well as some conspicuous and larger species of the orders Didelphimorphia (genera Chironectes Illiger, 1811, Didelphis Linnaeus, 1758, Metachirus Burmeister, 1854, and Philander Brisson, 1762), Lagomorpha (genus Sylvilagus Gray, 1867) and Rodentia (genera Hydrochoerus Brisson, 1762, Cuniculus Brisson, 1762, Dasyprocta Illiger, 1811, Myoprocta Thomas, 1903, and Coendou Lacépède, 1799). For cetaceans, we included only coastal and

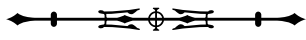


freshwater species (genera Inia d'Orbigny, 1834 and Sotalia Gray, 1866). The taxonomy of the species follows the latest comprehensive revisions published for each taxon:

(a) Stein \& Patton (2008), Cerqueira \& Tribe (2008), Patton \& Silva (2008), Gardner \& Dagosto (2008), Brandão et al. (2015), and Voss et al. (2018, 2019) for the large species of didelphids (Chironectes, Didelphis, Metachirus, and Philander);

(b) Wetzel et al. (2008) and Gardner (2008) for the orders Cingulata and Pilosa, respectively, except in the following cases: the armadillos are classified in the families Dasypodidae and Chlamyphoridae (Delsuc et al., 2016; Gibb et al., 2016); the taxonomic arrangements for longnosed armadillos (Dasypus Linnaeus, 1758), proposed by Feijó \& Cordeiro-Estrela (2016) and Feijó et al. (2018), and for silky anteaters (Cyclopes Gray, 1821), proposed by Miranda et al. (2017); the use of the name Choloepodidae instead of Megalonychidae for living two-toed sloths (Choloepus Illiger, 1811), as proposed by Delsuc et al. (2019);

(c) Shoshani (2005) and Grubb (2005a) for Sirenia and Perissodactyla, respectively;

(d) Wozencraft (2005) for Carnivora, except for Felidae, which we follow Segura et al. (2013) and Kitchener et al. (2017) in using Herpailurus Severtzov, 1858 as the generic name for the jaguarundi, and Nascimento \& Feijó (2017) for the taxonomy of the Leopardus tigrinus (Schreber, 1775) species group;

(e) Grubb (2005b) for Artiodactyla, except for Cervidae, which we adopted the arrangement proposed by Duarte \& González (2010), and for Tayassuidae (Acosta et al., 2020). Moreover, we keep the name Artiodactyla for the clade containing terrestrial artiodactyls and cetaceans, following Asher \& Helgen (2010). For the taxonomy of cetacean species, we follow Silva, V. \& Martin (2014) for Inia, and Caballero et al. (2007, 2008, 2010) for Sotalia;

(f) Mittermeier et al. (2013) for Primates, with the following updates: Garbino \& Martins-Junior (2018) for the genus-group taxa of callitrichines; Silva Jr. (2001), Feijó \& Langguth (2013), Garbino (2015), Gutiérrez \& Marinho-
Filho (2017), and Brandão et al. (2019) for the usage of Cebus Erxleben, 1777 and Sapajus Kerr, 1792 as subgenera of Cebus; Serrano-Villavicencio et al. (2017), Gutiérrez \& Marinho-Filho (2017), Garbino \& Aquino (2018), and Brandão et al. (2019) keeping Callicebus Thomas, 1903 for all titis and Plecturocebus Byrne, Rylands, Carneiro, LynchAlfaro, Bertuol, da Silva, Messias, Groves, Mittermeier, Farias, Hrbek, Schneider, Sampaio \& Boubli, 2016 as its subgenus (contra Byrne et al., 2016); Mercês et al. (2015) for the eastern Amazonian populations of Saimiri Voigt, 1831; and Serrano-Villavicencio et al. (2019) and Hershkovitz (1987) for the saki taxa (Pithecia spp.) from Pará state (contra Marsh, 2014). See the contents of each primate species for more details on taxonomic issues;

(g) Ruedas (2017) and Ruedas et al. (2017) for Sylvilagus Gray, 1867;

(h) For rodents, we have adopted the taxonomic arrangements proposed by Dunnum (2015) for Hydrochoerus, Patton (2015) for Cuniculus, Patton \& Emmons (2015) for Dasyprocta and Myoprocta, and Voss (2015) for Coendou.

We have included the conservation status of species based on the most recent assessments by the Instituto Chico Mendes de Conservação da Biodiversidade - Ministério do Meio Ambiente do Brasil (ICMBio, 2018) and the International Union for Nature Conservation (IUCN, 2019). The conservation status categories and their respective acronyms used here are: Least Concern (LC), Near Threatened (NT), Vulnerable (VU), Endangered (EN), Critically Endangered (CR), and Data Deficient (DD). We use Not Applicable (N/A) for taxa not identified at the species level or for domestic forms in a feral state, in the same manner as Brandão et al. (2019).

The geographical coordinates of the collection localities were obtained from gazetteers (Paynter Jr. \& Traylor Jr., 1991; Vanzolini, 1992) and the MZUSP localities index, elaborated by Paulo Emílio Vanzolini (unpublished data). All localities and their geographical coordinates are presented in the gazetteer available in the Appendix 1. Additionally, a map

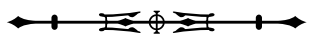


was elaborated with inclusion of the collection localities of the specimens listed here, showing the range of geographical distribution across Pará state. Specimens with 'unknown locality' were certainly collected in Pará state, however, we could not define the exact locality.

\section{RESULTS AND DISCUSSION}

\section{TAXONOMIC ACCOUNT AND LIST OF SPECIMENS}

\author{
Order Didelphimorphia Gill, 1872 \\ Family Didelphidae Gray, 1821
}

Genus Chironectes Illiger, 1811

Chironectes minimus (Zimmermann, 1780)

Common names: cuíca-d'água (Port.); water opossum (Eng.).

Records (1 locality and 22 specimens): Cametá, Rio Tocantins: MZUSP 4644 (skin and skull; female), 4654 (skin and skull; male), 4655-4656 (skin; male), 4657 (skin and skull; female), 4658 (skin and skull; male), 4659 (skin and skull; female), 4669-4670 (skin and skull; female), 4671 (skin; female), 4672-4673 (skin and skull; female), 4674 (skin; unknown sex), 4755 (skin and skull; female), 4757 (skin; female), 4759 (skin; male), 4762 (skin and skull; female), 4837 (skin and skull; male), 5334 (skin; unknown sex), 16544 (skull; male), 16545 (skull; female), 16585 (skull; female).

Conservation status: ICMBio (2018): DD; IUCN (2019): LC.

Genus Didelphis Linnaeus, 1758

Didelphis marsupialis Linnaeus, 1758

Common names: gambá-comum, gambá-de-orelhapreta, mucura, saruê, sarigueia (Port.); common opossum, black-eared opossum (Eng.).

Records (19 localities and 256 specimens): Ananindeua: MZUSP 8558-8560 (skull; female), 8561 (skull; unknown sex), 8562 (skull; male), 8563 (skull; male), 8565 (skull; unknown sex), 16549 (skull; unknown sex), 17099-17112 (skull; unknown sex), 17114-17118 (skull; unknown sex); Belém: 16546 (skull; unknown sex), 16555 (skin and skull; unknown sex), 16558 (skin and skull; male), 16560-16561 (skin; female), 16562 (skin; male), 16563 (skin; female), 17098 (skull; unknown sex), 17390 (skull; unknown sex), 17392 (skull; unknown sex), 19090 (skull; unknown sex), 19099-19103 (skull; unknown sex), 19111-19112 (skull; unknown sex), 19206 (skull; unknown sex), 19277 (skull; unknown sex), 19293 (skull; unknown sex), 19343 (skull; unknown sex), 19233 (skull; unknown sex), 19358 (skull; unknown sex); Boa Fé, Parque Nacional do Tapajós: 11867 (skin, skull and partial skeleton; female); BR-010, km 87-94: 17132 (skull; unknown sex), 17134-17135 (skull; unknown sex), 17138 (skull; unknown sex), 17140-17142 (skull; unknown sex), 17145-17150 (skull; unknown sex), 17153-17154 (skull; unknown sex), 17157-17165 (skull; unknown sex), 17167-17169 (skull; unknown sex), 17171-17173 (skull; unknown sex), 17176 (skull; unknown sex), 17178-17180 (skull; unknown sex), 17182-17190 (skull; unknown sex), 17192-17193 (skull; unknown sex), 17200-17203 (skull; unknown sex), 17205 (skull; unknown sex), 17207 (skull; unknown sex), 17238 17277 (skull; unknown sex); BR-010, km 92: 19092-19098 (skull; unknown sex), 19190-19208 (skull; unknown sex), 19234-19242 (skull; unknown sex), 19250 (skull; unknown sex), 19254-19265 (skull; unknown sex), 19267-19279 (skull; unknown sex), 19285 (skull; unknown sex), 19341 (skull; unknown sex), 19344-19348 (skull; unknown sex), 19350-19351 (skull; unknown sex), 19353-19355 (skull; unknown sex); BR-010, km 93: 8971 (skin and skull; male); Cachoeira do Espelho, Rio Xingu: 21311 (skin and skull; female), 21312 (skin and skull; male), 21313 (skull and skeleton; female), 21315 (skin, skull and skeleton; female); Cametá, Rio Tocantins: 4741 (skin and skull; male), 4742 (skin and skull; female), 4746 skin and skull; female), 4747 (skin and skull; male), 4748 (skin and skull; female), 4765-4766 (skin and skull; male), 4782 (skin and skull; 
female), 4784 (skin and skull; male), 10581 (skull; male), 10585 (skull; female), 10586 (skull; male), 10593 (skull; female), 10594 (skull; male), 10596 (skull; male), 20078 (skull; unknown sex); Capim: 19091 (skull; unknown sex); Caxiricatuba, Rio Tapajós: 4768 (skin and skull; female), 4786 (skin and skull; male), 4787 (skin; female), 4788 (skin and skull; male), 10589 (skull; male), 10595 (skull; female), 16547 (skull; female); Fordlândia: 12871 (skin and skull; female), 12872 (skin and skull; female); Igarapé Bravo, Rio Amazonas: 4781 (skin; male); Igarapé São José, near Itaituba: 11866 (skin, skull and partial skeleton; female); Pau de Letra, Rio Tapajós: 4743 (skin and skull; male), 4783 (skin and skull; male); Piquiatuba, Rio Tapajós: 10587 (skull; male); Santarém, Fazenda Marucu: 3653 (skull; unknown sex); São Miguel do Guamá: 8972 (skin and skull; female); Transamazônica km 15, near Itaituba: 11868 (skin; female), 11869 (skin and skull; male); Vila Bravo, Rio Tocantins: 13474-13475 (skull; unknown sex).

Conservation status: ICMBio (2018): LC; IUCN (2019): LC.

Genus Metachirus Burmeister, 1854

Metachirus myosuros (Temmink, 1824)

Common names: cuíca-de-quatro-olhos, cuícamarrom, jupati (Port.); brown four-eyed opossum (Eng.).

Records (10 localities and 51 specimens): BR-010, km 87: MZUSP 17018 (skin and skull; female); BR-010, km 8794: 17156 (skull; unknown sex), 17170 (skull; unknown sex), 17174 (skull; unknown sex), 17177 (skull; unknown sex), 17181 (skull; unknown sex); BR-010, km 92: 19116 (skull; unknown sex), 19246 (skull; unknown sex), 19251-19252 (skull; unknown sex), 19281-19282 (skull; unknown sex), 19298-19303 (skull; unknown sex), 19305-19308 (skull; unknown sex), 19312 (skull; unknown sex), 19342 (skull; unknown sex), 19352 (skull; unknown sex), 19357 (skull; unknown sex), 20039 (skull; unknown sex); Capim, BR010, km 94: 17019 (skin; female), 17020-17021 (skin and skull; female); Belém: 9782 (skin and skull; male), 9937 (skin and skull; female), 17022 (skin, skull and skeleton; female), 17023 (skull and skeleton; female), 17195 (skull; unknown sex), 17395 (skull; female), 19117 (skull; unknown sex), 19280 (skull; unknown sex), 19290-19291 (skull; unknown sex), 19309 (skull; unknown sex), 19311 (skull; unknown sex); Cachoeira do Espelho, Rio Xingu: 21305 (skin, skull and skeleton; male), 21334 (skin, skull and skeleton; female); Fordlândia: 17024 (skin and skull; male); Juruá, Rio Xingu: 25731 (in alcohol; female), 25732 (in alcohol; three fetuses of female 25731), 25733 (in alcohol; unknown sex); Piquiatuba, Rio Tapajós: 4527 (skin and skull; male); São Miguel do Guamá: 8964 (skin and skull; male), 8965 (skin and skull; female).

Conservation status: ICMBio (2018): LC; IUCN (2019): LC.

Comments: a single species, M. nudicaudatus (É. Geoffroy, 1803), with five subspecies in South America has been traditionally recognized in the genus (Gardner \& Dagosto, 2008). However, a recent study based on morphologic and molecular data has suggested the existence of more than a single species (Voss et al., 2019). Furthermore, $M$. nudicaudatus was restricted to the populations of Guyana, French Guiana, Suriname and the state of Amapá, in Brazil, while every other South American populations were provisionally placed in $M$. myosuros (Voss et al., 2019). The specimens of Metachirus present in the MZUSP collection are from localities south of the Rio Amazonas and they show the diagnostic characters of M. myosuros indicated by Voss et al. (2019), such as a small maxillopalatine fenestrae, large entoconids, strongly convergent temporalis and sagittal crest usually present.

\section{Genus Philander Brisson, 1762}

Philander opossum (Linnaeus, 1758)

Common names: cuíca-de-quatro-olhos, cuícaverdadeira (Port.); gray four-eyed opossum (Eng.).

Records (12 localities and 89 specimens): Ananindeua: MZUSP 17113 (skull; unknown sex); Belém: 9943 (skin and skull; male), 17066 (skin; male), 17197-17198 (skull; unknown sex), 17199 (skull; unknown sex), 17391 (skull; 
unknown sex), 19114-19115 (skull; unknown sex), 19243 (skull; unknown sex), 19247-19249 (skull; unknown sex), 19288 (skull; unknown sex), 19292 (skull; unknown sex), 19294 (skull; unknown sex), 19295-19296 (skull; unknown sex), 19356 (skull; unknown sex); Boiuçu: 4540 (skin and skull; female); BR-010, km 87: 17027 (skin; male), 19310 (skull; unknown sex); BR-010, km 87-94: 17152 (skull; unknown sex), 17155 (skull; unknown sex), 17175 (skull; unknown sex), 17204 (skull; unknown sex), 17206 (skull; unknown sex), 17278-17282 (skull; unknown sex); BR-010, km 92: 19113 (skull; unknown sex), 19244-19245 (skull; unknown sex), 19266 (skull; unknown sex), 19283-19284 (skull; unknown sex), 19286-19287 (skull; unknown sex), 19289 (skull; unknown sex), 19297 (skull; unknown sex), 19349 (skull; unknown sex); BR-010, km 94: 17026 (skin and skull; female), 17028-17029 (skin and skull; male); Cachoeira do Espelho, Rio Xingu: 21306 (skin, skull and skeleton; female), 21307 (skin and skull; male), 21308 (skin, skull and skeleton; female), 21309-21310 (skin, skull and skeleton; male), 21314 (skull and skeleton; male); Cametá, Rio Tocantins: 4535-4538 (skin; female), 4539 (skin; male), 4542 (skin and skull; male), 4543 (skin and skull; female), 4544-4646 (skin; male), 4648-4650 (skin; female), 4651 (skin and skull; male), 4652 (skin and skull; female), 4653 (skin and skull; male), 9941 (skin; male), 17031 (skull; male), 17063 (skull; male), 17064-17065 (skull; female), 17069 (skull; male), 17070 (skull; female), 17071-17072 (skull; male), 17073 (skull; female), 20079 (skull; unknown sex); Fordlândia: 17030 (skin and skull; female); Igarapé Taperebá, Ilha de Marajó: 8679 (skin, skull and skeleton; male); Rio Bacajá (mouth): 25454 (skin, skull and skeleton; male); São Miguel do Guamá: 8966 (skin and skull; male), 8967 (skin and skull; female), 8968-8969 (skin and skull; male), 8970 (skin and skull; female); Vila Bravo, Rio Tocantins: 13478 (skin and skull; unknown sex), 13479 (unknown sex).

Conservation status: ICMBio (2018): LC; IUCN (2019): LC. The recent taxonomic changes (see Comments) were not included in the latest conservation assessments by ICMBio (2018) and IUCN (2019).
Comments: Voss et al. (2018) revised the genus Philander, recognizing eight species: P. andersoni (Osgood, 1913), P. canus (Osgood, 1913), P. mcilhennyi Gardner \& Patton, 1972, P. melanurus (Thomas, 1899), P. opossum, $P$. pallidus (Allen, 1901), P. pebas Voss, Diaz-Nieto \& Jansa, 2018 and $P$. quica (Temminck, 1824). According to them, $P$. opossum occurs in Guyana, French Guiana, Suriname and the Eastern Brazilian Amazon (Amapá, Pará, Roraima, and part of Amazonas states), east of the Rio Negro and Rio Madeira, on both banks of the Rio Amazonas.

Order Cingulata Illiger, 1811

Family Chlamyphoridae Bonaparte, 1850

Genus Euphractus Wagler, 1830

Euphractus sexcinctus (Linnaeus, 1758)

Common names: tatu-peba, tatu-peludo (Port.); six-banded armadillo, yellow armadillo (Eng.).

Records (1 locality and 1 specimen): Cachimbo, Formiga: MZUSP 8035 (skin; male).

Conservation status: ICMBio (2018): LC; IUCN (2019): LC.

Genus Priodontes F. Cuvier, 1825

Priodontes maximus (Kerr, 1792)

Common names: tatu-canastra, tatuaçu (Port.); giant armadillo (Eng.).

Records (2 localities and 2 specimens): Reserva Biológica do Rio Trombetas: MZUSP 19995 (partial skull); Vila Bravo, Rio Tocantins: 13492 (skin, skull and skeleton).

Conservation status: ICMBio (2018): VU A2cd; IUCN (2019): VU A2cd.

Family Dasypodidae Gray, 1821

Genus Dasypus Linnaeus, 1758

Dasypus beniensis Lönnberg, 1942

Common names: tatu-de-quinze-quilos (Port.); greater long-nosed armadillo (Eng.).

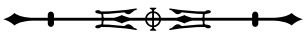


Records ( 1 locality and 3 specimens): Capim, Rodovia BR-14, km 93: MZUSP 8950 (skin and skull; unknown sex); Tavio, Rio Tapajós: 19973-19974 (skull; female).

Conservation status: ICMBio (2018): LC (as Dasypus kappleri); IUCN (2019): LC (as Dasypus kappleri). The recent taxonomic changes (see Comments) were not included in the latest conservation assessments by ICMBio (2018) and IUCN (2019). Therefore, this species was classified by these agencies as Dasypus kappleri.

Comments: Feijó \& Cordeiro-Estrela (2016) and Feijó et al. (2018) recently revalidated $D$. beniensis as full species, which traditionally was considered a junior synonym of D. k. pastasae (Thomas, 1901) (Cabrera, 1958; Gardner, 2005; Wetzel et al., 2008). Placed in the subgenus Hyperoambon Peters, 1864 by Wetzel \& Mondolfi (1979) and Feijó et al. (2019).

\section{Dasypus kappleri Krauss, 1862}

Common names: tatu-de-quinze-quilos (Port.); greater long-nosed armadillo (Eng.).

Records (1 locality and 1 specimen): As Pedras, Rio Cuminá-Miri: MZUSP 19967 (skin and skull; male).

Conservation status: ICMBio (2018): LC; IUCN (2019): LC. The recent taxonomic changes (see Comments) were not included in the latest conservation assessments by ICMBio (2018) and IUCN (2019).

Comments: traditionally D. kappleri has been considered a species with two subspecies, D. k. kappleri Krauss, 1862 and D. k. pastasae (Thomas, 1901) (Cabrera, 1958; Gardner, 2005; Wetzel et al., 2008), but Feijó \& Cordeiro-Estrela (2016) and Feijó et al. (2018) raised them as full species and revalidated $D$. beniensis (above), formerly junior synonym of $D$. k. pastasae. Placed in the subgenus Hyperoambon Peters, 1864 by Wetzel \& Mondolfi (1979) and Feijó et al. (2019).

\section{Dasypus novemcinctus Linnaeus, 1758}

Common names: tatu-galinha, tatuetê (Port.); ninebanded armadillo, long-nosed armadillo (Eng.).
Records (13 localities and 15 specimens): Alegre, 15 km NE Marapanim: MZUSP 19982 (skull; unknown sex); Bagagem, Rio Tocantins: 13485 (skin and skull; unknown sex); Cachimbo: 8073 (skin and skull; male), 19970 (skin and skull; unknown sex); Cachoeira do Espelho, Rio Xingu: 20923 (skin and skull; male), 20924 (skin and skull; female), 21301 (skin and skull; female); Caxiricatuba, Rio Tapajós: 5113 (skin and skull; female); Fordlândia: 19969 (skin and skull; female); Igarapé Jaramacaru: 19980 (skin; unknown sex); Piquiatuba, Rio Tapajós: 5112 (skin and skull; male); Rio Curuá (mouth): 5110 (skin; female); Transamazônica km 50, near Itaituba: 19965 (skin and skull; male); Transamazônica km 62. near Itaituba: 19981 (skull; unknown sex); Transamazônica km 75, near Itaituba: 19966 (partial skin; unknown sex).

Conservation status: ICMBio (2018): LC; IUCN (2019): LC.

Comments: $D$. novemcinctus has been traditionally treated as a polytypic species, with the number of recognized subspecies varying among different authors (Cabrera, 1958; Hall, 1981; McBee \& Baker, 1982; Gardner, 2005). However, Wetzel \& Mondolfi (1979) and Feijó et al. (2018) did not recognize any intraspecific subdivisions, and these later authors suggested that a comprehensive study to test geographic races is still needed. Dasypus novemcinctus was placed in the subgenus Dasypus by Feijó et al. (2019), together with D. pilosus (Fitzinger, 1856), D. mazzai Yepes, 1933, D. sabanicola Mondolfi, 1968 and an undescribed species from the Guianas.

\section{Dasypus septemcinctus Linnaeus, 1758}

Common names: tatu-galinha-pequeno, tatu-china, tatuí (Port.); Brazilian lesser long-nosed armadillo, sevenbanded armadillo (Eng.).

Records (3 localities and 3 specimens): Cachimbo: MZUSP 8111 (skin and skull; male); Soure, Fazenda Teso, Ilha de Marajó: 9970 (skin; unknown sex); Cametá, Rio Tocantins: 5111 (skin and skull; male).

Conservation status: ICMBio (2018): LC; IUCN (2019): LC. 
Comments: Feijó et al. (2018) recognized three subspecies: D. s. septemcinctus Linnaeus, 1758, D. s. hybridus (Desmarest, 1804) and D. s. cordobensis Feijó, Patterson \& Cordeiro-Estrela, 2018; the former occurring from the Amazon Basin to northern Argentina. Placed in subgenus Muletia Gray, 1874 by Feijó et al. (2019).

Order Pilosa Flower, 1883

Suborder Folivora Delsuc, Catzeflis, Stanhope \& Douzery, 2001

Family Bradypodidae Gray, 1821

Genus Bradypus Linnaeus, 1758

Bradypus tridactylus Linnaeus, 1758

Common names: preguiça-de-bentinho, preguiça-detrês-dedos (Port.); pale-throated sloth (Eng.).

Records (1 locality and 1 specimen): Igarapé Bravo, Rio Amazonas: 5302 (skin and skull; female).

Conservation status: ICMBio (2018): LC; IUCN (2019): LC.

Bradypus variegatus Schinz, 1825

Common names: preguiça-comum, preguiça-degarganta-marrom, preguiça-de-três-dedos (Port.); brownthroated sloth (Eng.).

Records (16 localities and 159 specimens): Aveiro: MZUSP 13504 (skin; female), 20003 (skull; female); Barreira, Rio Tapajós: 13507 (skin; female), 13509 (skin; female), 20005 (skull; female), 20006 (skull; female); Belém: 10660-10661 (skin and skull; female), 10663-10665 (skin and skull; male), 10666-10669 (skin and skull; female), 13510 (skin and skull; female), 23486-23598 (skull; unknown sex); Cachoeira do Espelho, Rio Xingu: 21327 (skin, skull and skeleton; female); Cametá, Rio Tocantins: 5429 (skin and skull; male), 5431 (skin and skull; female), 5432 (skin and skull; male), 5433 (skin; male), 5434 (skin and skull; female), 7118-7119 (skull; female), 13517 (skin and skull; male), 19918 (skull; female), 25209 (skin and skull; female); Caxiricatuba, Rio Tapajós: 5427 (skin and skull),
5430 (skin; unknown sex), 19914 (skin and skull; female), 19917 (skull; female); Fordlândia: 13515 (skeleton; female), 13495-13496 (skin and skull; female), 13497 (skin and skull; unknown sex), 13498 (skin and skull; male), 13499 (skin and skull; female), 13501-13502 (skin and skull; male); Igarapé São José, near Itaituba: 19902 (skull; unknown sex); Piquiatuba, Rio Tapajós: 5426 (skin and skull; female); Ilha de Santa Helena, Rio Pará: 13512 (skin and skull; female); Santarém, Alter do Chão: 19911 (formalina; unknown sex); Santarém, Fazenda Marucu: 3649-3650 (skin and skull; male); São Luís, Rio Tapajós: 13508 (skin; female), 20004 (skull; unknown sex); Transamazônica km 58, near Itaituba: 19929 (skin; unknown sex).

Conservation status: ICMBio (2018): LC; IUCN (2019): LC.

\section{Family Choloepodidae Gray, 1871}

Genus Choloepus Illiger, 1811

Choloepus didactylus (Linnaeus, 1758)

Common names: preguiça-real, preguiça-de-doisdedos, unau (Port.); Linnaeus's two-toed sloth (Eng.).

Records (6 localities and 8 specimens): $\underline{\text { Cachoeira }}$ do Espelho, Rio Xingu: MZUSP 21328 (skin, skull and skeleton; unknown sex); Cametá, Rio Tocantins: 5457 (skin; female), 5458 (skin; unknown sex), 19925 (skull; female); Morro da Terra Preta, Transamazônica km 60, near Itaituba: 19930 (skeleton; unknown sex); Óbidos: 3651 (skin and skull; male); Oriximiná: 19931 (skin; unknown sex); unknown locality: 8640 (skin; male) (ex-Zoo).

Conservation status: ICMBio (2018): LC; IUCN (2019): LC.

Comments: two-toed sloths were classified together with Bradypus in Bradypodidae (Simpson, 1945; Cabrera, 1958) or in a distinct family Choloepodidae (Wetzel \& Ávila-Pires, 1980). They have also been considered the living forms of the extinct family Megalonychidae (Wetzel, 1985; Gardner \& Naples, 2008). This latter view has been widely accepted for decades, but recent molecular studies 
have pointed out that Choloepus is phylogenetically close to the extinct Mylodontidae (Delsuc et al., 2019; Presslee et al., 2019). Thus, Choloepus was classified into a separate family, Choloepodidae, as some previous authors have proposed.

Suborder Vermilingua Illiger, 1811

Family Cyclopedidae Pocock, 1924

Genus Cyclopes Gray, 1821

Cyclopes didactylus (Linnaeus, 1758)

Common names: tamanduaí (Port.); common silky anteater, common pygmy anteater (Eng.).

Records (6 localities and 30 specimens): Arimateua, Rio Tocantins: MZUSP 19946 (skull; unknown sex); Belém: 8680 (skin, skull and skeleton; female), 8681 (skin, skull and skeleton; male), 24137 (skull; unknown sex); Igarapé Bravo, Rio Amazonas: 4696 (skin and skull; female); Cametá, Rio Tocantins: 4675-4678 (skin and skull; male), 4680 (skin and skull; male), 4681-4683 (skin and skull; female), 4684 (skin; male), 4685-4687 (skin and skull; female), 4689 (skin and skull; female), 4690 (skin; female), 4691-4692 (skin and skull; female), 4693-4695 (skin and skull, male), 4697 (skin and skull; female), 4698 (skin and skull; male), 4701 (skin and skull; female), 4702-4703 (skin; unknown sex), 19932 (skin, skull and skeleton; male).

Conservation status: ICMBio (2018): LC; IUCN (2019): LC.

Comments: a recent taxonomic revision recognizes seven species rather than a single polytypic species of silky anteater (Miranda et al., 2017). In this new arrangement, C. didactylus is the only species of the genus Cyclopes to have dorsal and ventral stripes clearly marked, and is found from eastern Venezuela, Trinidad, the Guianas, northeastern Brazilian Amazon (state of Pará, north of Rio Amazonas) towards states of Maranhão and Piauí, with a disjunct population in the northeastern Atlantic Forest (from the states of Rio Grande do Norte to Alagoas).
Cyclopes xinguensis Miranda, Casali, Perini, Machado \& Santos, 2018

Common names: tamanduaí (Port.); Xingu silky anteater, Xingu pygmy anteater (Eng.).

Records ( 3 localities and 8 specimens): Caxiricatuba, Rio Tapajós: MZUSP 4700 (skin and skull; female); Fordlândia: 19934 (skin and skull; female), 19935 (skin and skull; male), 19936 (skin; female), 19937-19938 (skin and skull; female), 19939 (skin and skull; male); Santarém: 3691 (skin and skull; female).

Conservation status: ICMBio (2018): LC (as Cyclopes didactylus); IUCN (2019): LC (as Cyclopes didactylus). The recent taxonomic changes (see Comments) were not included in the latest conservation assessments by ICMBio (2018) and IUCN (2019). Therefore, this species was classified by these agencies as Cyclopes didactylus.

Comments: Cyclopes xinguensis has been described by Miranda et al. (2017), who characterized the species as having a grayish body color with a dorsal stripe clearly marked, yellow rump and pale yellowish venter (Miranda et al, 2017). It is found in the region south of the Rio Amazonas, east of the Rio Madeira and west of the Rio Xingu (Miranda et al. , 2017).

Family Myrmecophagidae

Genus Myrmecophaga Linnaeus, 1758

Myrmecophaga tridactyla Linnaeus, 1758

Common names: tamanduá-bandeira, tamanduáaçu, tamanduá-cavalo, jurumim (Port.); giant anteater (Eng.).

Records (1 locality and 1 specimen): Fordlândia: MZUSP 19958 (skin and skull; female).

Conservation status: ICMBio (2018): VU A2c; IUCN (2019): VU A2c.

Genus Tamandua Gray, 1825

Tamandua tetradactyla (Linnaeus, 1758) 
Common names: tamanduá-mirim, tamanduáde-colete, melete (Port.); Southern tamanduá, collared anteater, lesser anteater (Eng.).

Records (13 localities and 38 specimens): Ananindeua: MZUSP 8566 (skin; unknown sex); Barreira, Rio Tapajós: 19959 (skin and skull; male); Belém: 23593-23594 (skull; unknown sex); Cachoeira do Espelho, Rio Xingu: 21329 (skin, skull and skeleton; male); Cametá, Rio Tocantins: 4979 (skin and skull; female), 5234 (skin and skull; male), 5236 (skin and skull; male), 5237-5239 (skin and skull; female), 5440 (skin and skull; female), 5442 (skin and skull; female), 5448-5449 (skin and skull; male), 5450 (skin; unknown sex), 5451 (skin and skull; male), 5452 (skin; male), 5453 (skin and skull; female), 10484 (skull; male), 19986 (skull; unknown sex); Capim, BR-010, km 93: 8999 (skin and skull; male); Caxiricatuba, Rio Tapajós: 4977 (skin; female), 5240 (skin and skull; female); Fordlândia: 19951 (skin and skull; male), 19952-19954 (skin and skull; female), 19960-19962 (skin and skull; female), 19972 (skin and skull; female), 20002 (skull and skeleton); Lago Jacaré, Rio Trombetas: 10708 (skin and skull; female); Óbidos: 3652 (skin and skull; female); Piquiatuba, Rio Tapajós: 5456 (skin and skull; male); Rio Curuá (mouth): 5454 (skin and skull; female); Santo Antônio, Rio Tocantins: 13484 (skin and skull; unknown sex).

Conservation status: ICMBio (2018): LC; IUCN (2019): LC.

Comments: T. tetradactyla presents body-color with great geographical variation, especially the vest (Wetzel, 1975). Most specimens from Pará in the MZUSP have a yellow body with a black or dark brown vest. However, one individual (MZUSP 3652) has the yellow body color with partial fading black vest, with a grayish appearance due to black hair with yellowish tips, while two others (MZUSP 5138 and 10708) are entirely yellow and without the vest. There are no records of melanistic specimens in the MZUSP collection.

Order Sirenia Illiger, 1811

Family Trichechidae Gill, 1872
Genus Trichechus Linnaeus, 1758

Trichechus inunguis (Natterer, 1883)

Common names: peixe-boi-da-amazônia, manati (Port.); Amazonian manatee (Eng.).

Records (3 localities and 3 specimens): Lago Sapucuá, Rio Trombetas: MZUSP 19535 (skull and skeleton; unknown sex); Óbidos: 19545 (skull and skeleton; male); Oriximiná: 19544 (skull and skeleton; unknown sex).

Conservation status: ICMBio (2018): VU A4cd; IUCN (2019): VU A3cd.

Order Carnivora Bowdich, 1821

Suborder Caniformia Kretzoi, 1943

Family Canidae Fischer, 1817

Genus Atelocynus Cabrera, 1940

Atelocynus microtis (Sclater, 1883)

Common names: cachorro-do-mato-de-orelhascurtas, raposa-de-orelhas-pequenas (Port.); short-eared dog, short-eared zorro, small-eared dog (Eng.).

Records (2 localities and 5 specimens): Fordlândia: MZUSP 19751 (skin, skull and skeleton; male), 19752 (skin, skull and skeleton; female), 19753 (skin and skull; male), 19754 (skin and skull; male); Morro da Terra Preta, Transamazônica km 60, near Itaituba: 19750 (skull and partial skeleton).

Conservation status: ICMBio (2018): VU A2c; IUCN (2019): NT.

Genus Cerdocyon C.E.H. Smith, 1839

Cerdocyon thous (Linnaeus, 1766)

Common names: cachorro-do-mato, lobinho, lobete (Port.); crab-eating fox (Eng.).

Records (2 localities and 2 specimens): Canaã dos Carajás: MZUSP 34778 (skull; unknown sex); unknown locality: 2762 (skull; unknown sex).

Conservation status: ICMBio (2018): LC; IUCN (2019): LC.

Comments: the oldest MZUSP specimen from Pará is MZUSP 2762, already identified as Cerdocyon thous and 
collected in 1909. Originally, this specimen was a stuffed animal with a separated skull; however, only the skull was found.

Family Procyonidae Gray, 1825

Genus Nasua Storr, 1780

Nasua nasua (Linnaeus, 1766)

Common names: quati, quati-de-cauda-anelada, quati-de-nariz-marrom (Port.); South American coati, ringtailed coati (Eng.).

Records (15 localities and 28 specimens): $\underline{\text { Baixo }}$ Amazonas: MZUSP 19785 (skin; unknown sex); Igarapé Bravo, Rio Amazonas: 5540 (skin and skull; female); Cachimbo: 8034 (skin; female); Cachoeira do Espelho, Rio Xingu: 20926 (skin and skull; male), 21333 (skin, skull and skeleton; female); Cametá, Rio Tocantins: 5233 (skin; female), 5242 (skin and skull; male), 7157 (skull; female); Caxiricatuba, Rio Tapajós: 5228 (skin and skull; female), 5230 (skin and skull; female), 5247 (skin and skull; female), 5251 (skin and skull; female); Fordlândia: 19777 (skin and skull; female), 19781 (skin and skull; female), 19783 (skin and skull; male), 19784 (skin and skull; female); Ilha do Limão, Rio Xingu: 25456 (skin, skull and skeleton; male); Itaituba: 24834 (skull; unknown sex), 24835 (skull; male); Monte Cristo, Rio Tapajós: 19773 (skin and skull; female); Piquiatuba, Rio Tapajós: 5241 (skin; female); Rio Curuá (mouth): 5246 (skin and skull; female); Santarém, Fazenda Marucu: 3648 (skin; male); Sumaúma, Rio Tapajós: 19765 (skin and skull; male), 19768 (skin and skull; female); Urucurituba, Rio Tapajós: 19778-19779 (skin and skull; female), 19780 (skin and skull; male).

Conservation status: ICMBio (2018): LC; IUCN (2019): LC.

Genus Potos É Geoffroy \& F.G. Cuvier, 1795 Potos flavus (Schreber, 1774)

Common names: jupará, jurupará, macaco-da-noite (Port.); kinkajou (Eng.).
Records (5 localities and 7 specimens): Belém: MZUSP 8645 (skin; male); Cachoeira do Espelho, Rio Xingu: 21330 (skin, skull and skeleton; female); Cametá, Rio Tocantins: 5534 (skin and skull; male), 5563 (skin and skull; female), 5564(skin; male); Capim: 8951 (skin and skull, female); Fordlândia: 12000 (skin and skull; male).

Conservation status: ICMBio (2018): LC; IUCN (2019): LC.

\section{Genus Procyon Storr, 1780}

Procyon cancrivorus (G. Cuvier, 1798)

Common names: mão-pelada, guaxinim, jaguacinim (Port.); crab-eating raccoon, South American raccoon (Eng.).

Records (2 localities and 2 specimens): Cametá, Rio Tocantins: MZUSP 5559 (skin and skull; female); Fordlândia: 19794 (skin and skull; male).

Conservation status: ICMBio (2018): LC; IUCN (2019): LC.

\section{Family Mustelidae Fischer, 1817}

Genus Eira C.E.H. Smith, 1842

Eira barbara (Linnaeus, 1758)

Common names: irara, papa-mel, jaguapé (Port.); tayra (Eng.).

Records (9 localities and 30 specimens): Boiuçu: MZUSP 5183 (skin and skull; female), 5186 (skin and skull; female), 5195 (skin and skull; female); Caxiricatuba, Rio Tapajós: 5184 (skin and skull; male), 5187 (skin and skull; male), 5190 (skin, female), 5275 (skin and skull; male), 19845 (skull; female); Fordlândia: 10143 (skin and skull; female), 10144 (skin and skull; male), 10145 (skin and skull; female), 19798 (skull and skeleton; male), 19800-19801 (skin and skull; female), 19803 (skin and skull; female), 19804 (skin and skull; male), 19805-19806 (skin and skull; female), 19808-19809 (skin and skull; female), 19810 (skin and skull; male), 19811-19812 (skull; unknown sex), 19813 (skull and skeleton; female); Óbidos: 3672 (skin and skull; female); 
Rio Tapajós: 19825 (skin; unknown sex); Tauari, Rio Tapajós: 19799 (skin and skull; female); Urucurituba, Rio Tapajós: 19802 (skin and skull; female), 19807 (skin and skull; male); unknown locality: 8642 (skin, skull and skeleton; female).

Conservation status: ICMBio (2018): LC; IUCN (2019): LC.

Comments: all specimens in the MZUSP have the typical coat color pattern, i.e., trunk, limbs, and tail black or dark brown contrasting with light-colored head and neck (grayish bronze, grayish brown or light yellow), except one individual, MZUSP 5186 (from Boiuçu), which has the body entirely whitish-yellow. Entirely dark specimens are not represented in the MZUSP collection.

\section{Genus Galictis Bell, 1826}

Galictis vittata (Schreber, 1776)

Common names: furão, furão-grande (Port.); greater grison (Eng.).

Records (3 localities and 3 specimens): Belém: MZUSP 19826 (skin and skull; female); Brasília Legal, Rio Tapajós: 19824 (skin; female); Sumaúma, Rio Tapajós: 19823 (skin; male)

Conservation status: ICMBio (2018): LC; IUCN (2019): LC.

Comments: genus Galictis revised by Bornholdt et al. (2013). Galictis vittata distinguishes from its sister species, G. cuja (Molina, 1782), by its shorter fur, larger body size and presence of metaconid in the $\mathrm{m} 1$ (Yensen \& Tarifa, 2003a, 2003b; Bornholdt et al., 2013).

\section{Genus Mustela Linnaeus, 1758}

Mustela africana Desmarest, 1818

Common names: doninha-amazônica (Port.); Amazon weasel, tropical weasel (Eng.).

Records (3 localities and 3 specimens): Icoaraci: MZUSP 6632 (skin; female); Tauari, Rio Tapajós: 19828 (skin; male); unknown locality: 24837 (skin; male).

Conservation status: ICMBio (2018): DD; IUCN (2019): LC.
Comments: there is scarce information regarding this species in the literature, with only a few specimens known to exist worldwide, collected mainly in the early 20th century (Oliveira, T., 2009; Ramírez-Chaves et al., 2014). According to the Global Biodiversity Information Facility (GBIF, 2019), only 31 specimens are housed in mammals' collections from Europe, USA, and Brazil. Thus, the specimens preserved at the MZUSP have a high scientific value for this poorly sampled species.

Genus Pteronura Gray, 1837

Pteronura brasiliensis (Zimmerman, 1780)

Common names: ariranha, lontra-gigante, onçad'água (Port.); giant otter, giant river otter (Eng.).

Records (1 locality and 1 specimen): Cachimbo: MZUSP 8061 (skin and skull; male).

Conservation status: ICMBio (2018): VU A3cd; IUCN (2019): EN A3ce.

Suborder Feliformia Kretzoi, 1945

Family Felidae Fischer, 1817

Genus Herpailurus Severtzov, 1858

Herpailurus yagouaroundi (É. Geoffroy, 1803)

Common names: jaguarundi, gato-mourisco (Port.); jaguarundi (Eng.).

Records ( 4 localities and 7 specimens): Cametá, Rio Tocantins: MZUSP 5175-5176 (skin and skull; female); Fordlândia: 13598 (skin and skull; female), 13606 (skin and skull; female), 13607 (skin and skull; male); Óbidos: 3692 (skull; unknown sex); Puraquecuara, Rio Tocantins: 13481 (skin, skull and skeleton; unknown sex).

Conservation status: ICMBio (2018): VU C1; IUCN (2019): LC

Comments: all specimens of jaguarundi from Pará state in the MZUSP are brownish or blackish gray, except for MZUSP 13598 (from Fordlândia), which has a reddish pelage. 
Genus Leopardus Gray, 1842

Leopardus emiliae (Thomas, 1914)

Common names: gato-do-mato-pequeno, gato-domato-pequeno-do-norte, gato-macambira (Port.); Eastern tigrina, Snethlage's tigrina (Eng.).

Records (1 locality and 1 specimen): Terra Santa, Rio lamari: MZUSP 13605 (skin, skull and skeleton; female).

Conservation status: ICMBio (2018): EN C2 (as Leopardus tigrinus); IUCN (2019): VU A2c (as Leopardus tigrinus).

Comments: previously considered a junior synonym of L. tigrinus (Schreber, 1775), Eastern or Snethlage's tigrina has been raised to species rank by Nascimento \& Feijó (2017).

Leopardus pardalis (Linnaeus, 1758)

Common names: jaguatirica, maracajá-açu (Port.); ocelot (Eng.).

Records (5 localities and 6 specimens): As Pedras, Rio Cuminá-Miri: MZUSP 13595 (skull and skeleton; unknown sex); Curuá, Lago Cuiteuá, Rio Amazonas: 5553 (skin and skull; male); Ponta de Pedras, llha de Marajó: 29025 (skin; male); Vila Bravo, Rio Tocantins: 13470 (skin and skull; unknown sex); unknown Locality: 8633-8634 (skin, skull and skeleton; male).

Conservation status: ICMBio (2018): LC; IUCN (2019): LC.

Leopardus wiedii (Schinz, 1821)

Common names: maracajá, maracajá-mirim, gatopeludo (Port.); margay (Eng.).

Records (2 localities and 4 specimens): Anajás: MZUSP 13604 (skin; male); Cametá, Rio Tocantins: 5560 (skin and skull; male), 5561 (skull; male), 5562 (skin and skull; male).

Conservation status: ICMBio (2018): VU C1; IUCN (2019): NT.

Genus Puma Jardine, 1834 Puma concolor (Linnaeus, 1771)
Common names: suçuarana, onça-parda, onçavermelha, puma (Port.); cougar, mountain lion, puma (Eng.).

Records (2 localities and 2 specimens): Serra do Cachimbo: MZUSP 8121 (skin and skull; female); Transamazônica km 46: 24904 (skull; unknown sex).

Conservation status: ICMBio (2018): VU C1; IUCN (2019): LC.

Genus Panthera Oken, 1816

Panthera onca (Linnaeus, 1758)

Common names: onça-pintada, jaguar, jaguaretê (Port.); jaguar (Eng.).

Records(3 localitiesand 4specimens): Taperinha: MZUSP 3685 (skin and skull; male), 3686 (skull; male); Transamazônica km 100: 13596 (mandible and skeleton); Vila Bravo, Rio Tocantins: 13493 (skin, skull and skeleton; unknown sex).

Conservation status: ICMBio (2018): VU A2bcd + 3cd; C1; IUCN (2019): NT.

Order Artiodactyla Owen, 1848

Suborder Ruminantia Scopoli, 1777

Infraordem Pecora Flower, 1883

Family Bovidae Gray, 1821

Genus Bubalus C.E.H. Smith, 1827

Bubalus bubalis (Linnaeus, 1758)

Common names: búfalo-d'água, búfalo-asiático (Port.); water buffalo, domestic water buffalo (Eng.).

Records (1 locality and 1 specimen): Ilha de Marajó: no record number (horns; unknown sex).

Conservation status: N/A.

Comments: species introduced in the region in the last decade of the 19th century, with populations currently living in a semi-feral state (Tiepolo \& Tomas, 2011).

Family Cervidae Goldfuss, 1820

Genus Mazama Rafinesque, 1817 Mazama americana (Erxleben, 1777)

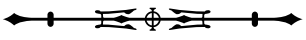


Common names: veado-mateiro, veado-vermelho, veado-pardo, suaçupita (Port.); red brocket deer (Eng.).

Records (7 localities and 13 specimens): Cachimbo: MZUSP 8039 (skin; female); Caxiricatuba, Rio Tapajós: 5483 (skin; female); Capim, BR-010, km 94: 9627 (skin and skull; female), 9628 (skull; female), 9629 (skin and skull; female), 9630 (skin and skull; male), 9631 (skin and skull; female); Fordlândia: 13562 (skin and skull; female); Itaituba, Parque Nacional da Amazônia: 13570 (skull; male); Lago Jacaré, Rio Trombetas: 10713 (skin and skull; female); Vila Bravo, Rio Tocantins: 13494 (skull; unknown sex), 13516 (skin; unknown sex), 19996 (skull; unknown sex).

Conservation status: ICMBio (2018): DD; IUCN (2019): DD.

Mazama nemorivaga (F. Cuvier, 1817)

Common names: veado-roxo, fuboca (Port.); Amazonian brown brocket deer, small brown brocket deer (Eng.).

Records ( 5 localities and 26 specimens): Caxiricatuba, Rio Tapajós: MZUSP 4994 (skin; male), 4995 (skin; unknown sex), 4997 (skin and skull; male), 4998-4999 (skin; female), 5177 (skin; female), 5260 (skin and skull; female), 5261 (skin and skull; male), 7163 (skull; female), 7165 (skull; male), 7263 (skin; unknown sex), 13559 (skull; male); Fordlândia: 10150 (skin and skull; female), 13563 (skin and skull; male), 13573 (skin and skull; female), 13575 (skin and skull; male), 13576 (skin and skull; female), 13577-13579 (skin and skull; male); Pimental: 19994 (skull; unknown sex); Rio Curuá-Una (mouth): 5262 (skin and skull; female); Tauari, Rio Tapajós: 13564 (skin and skull; male), 13565 (skin and skull; female), 13566 (skin and skull; male), 13567 (skin and skull; female).

Conservation status: ICMBio (2018): DD; IUCN (2019): LC.

Suborder Suina Gray, 1868

Family Tayassuidae Palmer, 1897
Genus Dicotyles Cuvier, 1816

Dicotyles tajacu (Linnaeus, 1758)

Common names: caititu, cateto, porco-do-mato (Port.); collared peccary (Eng.).

Records (7 localities and 9 specimens): Aruã, Rio Arapiuns: MZUSP 5339 (skin and skull; female); Cametá, Rio Tocantins: 5338 (skin and skull; female); Capim, BR010, km 93: 8942 (skull; male); llha de Nova Olinda, Rio Tapajós: 20022 (skull; unknown sex); Rio Curuá (mouth): 5335 (skin; male), 5340 (skin and skull; female); Transamazônica km 80, near Itaituba: 20019 (skull; unknown sex); Vila Bravo, Rio Tocantins: 13488 (skin and skull; unknown sex), 13490 (skin and skull; unknown sex).

Conservation status: ICMBio (2018): LC; IUCN (2019): LC.

Comments: Acosta et al. (2020) solved the nomenclatural issues involving peccaries and according to these authors the valid genus for the collared peccary is Dicotyles Cuvier, 1816, with Pecari Reichenbach, 1835 as its junior synonym.

\section{Genus Tayassu Fischer, 1814}

Tayassu pecari (Link, 1795)

Common names: queixada, porco-do-mato (Port.); white-lipped peccary (Eng.).

Records (6 localities and 15 specimens): Cachimbo: MZUSP 8087 (skull; female); Caxiricatuba, Rio Tapajós: 5437 (skin and skull; male), 5594 (skin and skull; male), 5597 (skin and skull; male), 5598 (skin; male), 5599 (skin and skull; male); Fordlândia: 20014 (skin and skull; male); Parque Nacional da Amazônia, Rio Tapajós: 20016 (skull; unknown sex), 20017 (skull; unknown sex); Uruá, Rio Tapajós: 20018 (skull; unknown sex), 20020 (mandible; unknown sex), 20021 (partial skull; unknown sex); Vila Bravo, Rio Tocantins: 13487 (skull; unknown sex), 13489 (skin and skull; unknown sex), 13491 (skin, skull and partial skeleton; female).

Conservation status: ICMBio (2018): VU A2abcde+3abcde; IUCN (2019): VU A2bcde+3bcde.

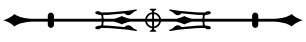


Suborder Whippomorpha Wadell, Okada \& Hasegawa, 1999

Infraorder Cetacea Brisson, 1762

Family Delphinidae Gray, 1821

Genus Sotalia Gray, 1866

Sotalia fluviatilis (Gervais \& Deville, 1853)

Common names: tucuxi, pirajaguara, boto-preto (Port.); tucuxi (Eng.).

Records (2 localities and 3 specimens): Lago Jacaré, Rio Trombetas: MZUSP 18946 (skull; female), 19913 (skull; unknown sex); Oriximiná: 18924 (skeleton; female).

Conservation status: ICMBio (2018): NT; IUCN (2019): DD.

Sotalia guianensis (Van Beneden, 1864)

Common names: boto-cinza (Port.); Guiana dolphin (Eng.).

Records (2 localities and 2 specimens): Maracanã, llha de Maiandeua, Algodoal: MZUSP 27383 (skull; unknown sex); Marapanim, Marudá: 28413 (partial skull; unknown sex).

Conservation status: ICMBio (2018): VU A3bcde; IUCN (2019): NT A2d+3d+4d.

Family Iniidae Gray, 1846

Genus Inia d'Orbigny, 1834

Inia geoffrensis (Blainville, 1817)

Common names: boto, boto-cor-de-rosa, boto-rosa, boto-vermelho (Port.); boto, Amazon river dolphin, pink river dolphin (Eng.).

Records (2 localities and 2 specimens): Lago Jacaré, Rio Trombetas: MZUSP 18871 (skull; male); Taperinha: 18883 (skull; female).

Conservation status: ICMBio (2018): EN A3cde; IUCN (2019): EN A2acd+3cd+4acd.

Comments: traditionally, a single polytypic species has been recognized for Amazonian river dolphins, but the number of subspecies is a matter of debate, with authors recognizing two subspecies I. g. geoffrensis and $I$. g. boliviensis (d'Orbigny, 1834) (Committee on Taxonomy, 2017), while others recognize a third $I$. g. humboldtiana Pilleri \& Gihr, 1977 (Mead \& Brownell Jr., 2005). Moreover, for some authors (Martínez-Agüero et al., 2006) at least one of these subspecies (I. g. boliviensis) would be a full species. Recently some studies (Hrbek et al., 2014; Siciliano et al., 2016) have pointed out that the populations present in the Rio Araguaia Basin are a valid species, named $I$. araguaiaensis Hrbek, da Silva, Dutra \& Farias, 2014, which is not represented in the MZUSP.

Order Perissodactyla Owen, 1848

Family Tapiridae Gray, 1821

Genus Tapirus Brisson, 1762

Tapirus terrestris (Linnaeus, 1758)

Common names: anta, tapir (Port.); lowland tapir, South American tapir, Brazilian tapir (Eng.).

Records (3 localities and 5 specimens): Ilha da Nova Olinda, Rio Tapajós: MZUSP 20037 (skull; unknown sex); Lago Jacaré, Rio Trombetas: 10715 (skull; unknown sex), 20035 (skin and skull; female), 20036 (skin and skull; male); Transamazônica km 66, Parque Nacional da Amazônia: 20033 (skull; unknown sex).

Conservation status: ICMBio (2018): VU A2bcd+3bcd; IUCN (2019): VU A2cde+3cde.

Comments: Cozzuol et al. (2013) described a new species of tapir from Brazilian and Colombian Amazon, named as Tapirus kabomani Cozzuol, Clozato, Holanda, Rodrigues, lenow, Thoisy, Redondo \& Santos, 2013. However, the validity of this species has been questioned by some authors (Voss et al., 2014; Ruiz-García et al., 2016) due to morphologic and genetic similarities with $T$. terrestris. Thus, here we provisionally treat T. kabomani as a junior synonym for T. terrestris.

Order Primates Linnaeus, 1758

Suborder Haplorhini Pocock, 1918 
Family Cebidae Bonaparte, 1821

Subfamily Callitrichinae Gray, 1821

Genus Mico Lesson, 1840

Mico argentatus (Linnaeus, 1771)

Common names: sagui-branco, sagui-argênteo (Port.); silvery marmoset (Eng.).

Records (8 localities and 55 specimens): Cametá, Rio Tocantins: MZUSP 4833 (skin and skull; female), 4916 (skin and skull; female), 4967 (skin and skull; male), 4968 (skin and skull; female); Caxiricatuba, Rio Tapajós: 4829 (skin; female), 4865 (skin and skull; female), 4900 (skin and skull; male), 4901 (skin and skull; female), 4902 (skin; female), 4903 (skin; male), 4904 (skin and skull; female), 4906-4907 (skin and skull; female), 4908-4909 (skin and skull; male), 4911 (skin and skull; male), 4913 (skin and skull; female), 4940 (skin and skull; male), 4959 (skin and skull; female), 4964-4966 (skin and skull; male), 4969-4970 (skin and skull; male), 4972-4974 (skin and skull; male), 4975 (skin and skull; female), 5007 (skin and skull; male), 5026 (skin and skull; female), 11407 (skin and skull; male), 18865 (skull; female); Piquiatuba, Rio Tapajós: 4840 (skin and skull; male), 4899 (skin and skull; male), 4905 (skin and skull; female), 4910 (skin and skull; female), 4914 (skin and skull; female), 4915 (skin and skull; male), 4918 (skin and skull; male); OS Patos: 11367 (skin, skull and skeleton; female); Santarém: 6633 (skin; female); Santarém, Fazenda Marucu: 3588-3589 (skin and skull; female), 3590 (skull; female), 3591 (skin and skull; female), 3592 (skull; male), 3593 (skin and skull; male), 3594-3596 (skin and skull; female); Santarém: 4971 (skin and skull; male); Tauari, Rio Tapajós: 4313 (skin and skull; male), 11272 (skin and skull; male), 11307-11308 (skin and skull; male); unknown locality: 3587 (skull; unknown sex).

Conservation status: ICMBio (2018): LC; IUCN (2019): LC.

Mico humeralifer (É. Geoffroy Saint-Hilaire, 1812)

Common names: sagui-de-tufos (Port.); black and white tassel-ear marmoset (Eng.).
Records (7 localities and 67 specimens): Arara, Rio Tapajós: MZUSP 11396 (skin; male); Barreira, Rio Tapajós: 11360 (skin and skull; male); Boim: 4927 (skin; female), 7108 (skull; female); Brasília Legal, Rio Tapajós: 11294 (skin and skull; male), 11298 (skin and skull; female), 11299 (skin and skull; male), 11300 (skin and skull; female), 11301 (skin and skull; female), 11306 (skin and skull; female), 11309-11310 (skin and skull; male), 11312 (skin and skull; female); Itaituba: 3577 (skin and skull; female), 3578-3580 (skin and skull; male), 3581 (skull; female), 3582 (skin and skull; male), 3583 (skull; male), 3584 (skin and skull; female), 3585-3586 (skin and skull; male); Monte Cristo, Rio Tapajós: 3597 (skull; male); Santa Rosa, llha de Urucurituba: 11397 (skin and skull; male), 11398 (skin and skull; female), 11399 (skin and skull; male), 11400 (skin and skull; female), 11401 (skin and skull; male); Sumaúma, Rio Tapajós: 11254 (skin and skull; male), 11264 (skin and skull; female), 11265-11266 (skin and skull; male), 11267 (skin and skull; unknown sex), 11268-11270 (skin and skull; male), 11271 (skin and skull; female), 11297 (skin and skull; male), 11302 (skin and skull; male), 11303-11304 (skin and skull; female), 11332 (skin and skull; male), 11333 (skin and skull; female); Transamazônica, km 62, near Itaituba: 18866 (skin and skull; male); Urucurituba, Rio Tapajós: 10095-10099 (skin and skull; male); 11249-11253 (skin and skull; male), 11255 (skin and skull; female), 11256 (skin and skull; male), 11257-11258 (skin and skull; female), 11259 (skin and skull; male), 11260 (skin and skull; female), 11261-11262 (skin and skull; male), 11263 (skin and skull; female), 11356-11358 (skin and skull; female).

Conservation status: ICMBio (2018): LC; IUCN (2019): DD.

Mico leucippe Thomas, 1922

Common names: sagui-de-orelha-nua-branco (Port.); white marmoset, golden-white bare-ear marmoset (Eng.).

Records (6 localities and 22 specimens): Fordlândia: MZUSP 10093 (skin and skull; male), 11248 (skin and skull; female), 11279-11280 (skin and skull; male), 11281 (skin and 
skull; female), 11291 (skin and skull; male), 11295-11296 (skin and skull; female), 11305 (skin and skull; female), 11311 (skin and skull; male); Fordlândia, Fazenda Nova: 11402 (skin; male), 11403 (skin and skull; female); Lago Araipá, Rio Tapajós: 9965 (skin; male); Monte Cristo, Rio Tapajós: 3598-3599 (skin and skull; male), 3600 (skin and skull; female), 3602-3603 (skin and skull; female), 11361 (skin and skeleton; female); Pedreira, Rio Tapajós: 9964 (skin; male); Tavio, Rio Tapajós: 10094 (skin and skull; female), 11394 (skin; male).

Conservation status: ICMBio (2018): LC; IUCN (2019): VU A2c.

Genus Saguinus Hoffmannsegg, 1807

Subgenus Saguinus Hoffmannsegg, 1807

Saguinus midas (Linnaeus, 1758)

Common names: sagui-de-mãos-douradas, sagui-demãos-amarelas (Port.); golden-handed tamarin, red-handed tamarin, Midas tamarin (Eng.).

Records (8 localities and 46 specimens): Boiuçu: MZUSP 4830 (skin and skull; female), 4834 (skin and skull; male), 4863 (skin and skull; male), 4868 (skin; male), 4869 (skin and skull; male), 4872 (skin and skull; female), 4877 (skin and skull; male), 4930 (skin and skull; male), 4935-4936 (skin and skull; male), 4941 (skin and skull; female), 4944 (skin and skull; female), 4948 (skin and skull; female), 5000 (skin and skull; male), 5013 (skin and skull; male), 5021 (skin and skull; female); Igarapé Bravo, Rio Amazonas: 4866 (skin and skull; female), 4867 (skin and skull; male), 4870 (skin and skull; female), 4871 (skin and skull; male), 4873-4875 (skin and skull; female), 4876 (skin and skull; male), 4878-4879 (skin and skull; male), 4958 (skin and skull; male), 4960 (skin and skull; female), 4961 (skin and skull; male), 4962 (skin; male), 4963 (skin and skull; female); Cacaoal Grande: 3604 (skin and skull; male), 3605 (skin and skull; female); Curuá, Lago Cuiteuá, Rio Amazonas: 4306 (skin; female); Óbidos: 3606-3607 (skin and skull; female), 3608-3610 (skin and skull; male),
3611-3612 (skull; male); Oriximiná: 11343-11344 (skin and skeleton; female); Paissandu, Igarapé Bom Jardim: 7170 (skull; female); Rio Cuminá-Miri (mouth): 11341 (skin and skull; male), 11342 (skin and skull; unknown sex).

Conservation status: ICMBio (2018): LC; IUCN (2019): LC.

Comments: Gregorin \& de Vivo (2013) examined two specimens (MZUSP 2867 and 7170) from Bom Jardim, Pará state, identifying them as Saguinus ursula Hoffmannsegg, 1807, but this locatity falls within the geographical distribution of $S$. midas. One of these specimens cited by Gregorin \& de Vivo (2013), MZUSP 2867, was not found in the collection and this registration number is occupied by a Didelphis aurita Wied, 1826 (from Bauru, São Paulo state), which was discarded decades ago due to damages on the skin.

Saguinus niger (É. Geoffroy, 1803)

Common names: sagui-una, sagui-preto (Port.); Western black tamarin, Western black-handed tamarin (Eng.).

Records (5 localities and 24 specimens): Cametá, Rio Tocantins: MZUSP 4749 (skin; male), 4750 (skin and skull; male), 4790 (skin and skull; male), 4792-4793 (skin and skull; female), 4794 (skin and skull; male), 4795-4796 (skin and skull; female), 4825 (skin and skull; male), 4922 (skin and skull; male), 4926 (skin and skull; male), 4933 (skin and skull; female), 4937 (skin and skull; female), 4946 (skin and skull; male), 4950 (skin and skull; male), 4951 (skin and skull; female), 4954 (skin and skull; male), 4955 (skin and skull; female), 20042 (skin and skull; female); Cachoeira do Espelho, Rio Xingu: 21321 (skin and skeleton; female), 21322 (skin and skeleton; male); Rio Bacajá (mouth): 25447 (skin, skull and skeleton; male); Santana do Araguaia, Fazenda Fartura: 35403 (skin; female); Santo Antonio, Rio Tocantins: 13471 (skin and skull; unknown sex).

Conservation status: ICMBio (2018): VU A4c; IUCN (2019): VU A2c. 
Saguinus ursula Hoffmannsegg, 1807

Common names: sagui-una, sagui-preto (Port.); Eastern black tamarin, Eastern black-handed tamarin (Eng.).

Records (2 localities and 43 specimens): Belém: MZUSP 10658 (skin and skull; female), 11247 (skin and skull; male), 19035-19061 (skull; unknown sex), 19076 (skull; unknown sex); BR-010, km 93: 8923-8928 (skin and skull; male), 8929-8933 (skin and skull; female), 8934 (skin and skull; male), 8935 (skin and skull; female).

Conservation status: ICMBio (2018): VU A4c (as part of S. niger); IUCN (2019): VU A2c (as part of S. niger). Due to its being recently split from Saguinus niger, this species was not included in the assessments of ICMBio (2018) and IUCN (2019).

Comments: this species was revalidated by Gregorin \& de Vivo (2013). We follow Garbino \& Martins-Junior (2018, p. 168) in using Saguinus ursula instead of Saguinus ursulus because "this species was named after a proper noun and treat it as a noun in apposition".

Subfamily Cebinae Bonaparte, 1841

Genus Cebus Erxleben, 1777

Subgenus Cebus Erxleben, 1777

Cebus (Cebus) kaapori Queiroz, 1992

Common names: caiarara, caiara (Port.); Kaapori capuchin (Eng.).

Records (1 locality and 1 specimen): Bragança: MZUSP 8252 (skin and skull; unknown sex).

Conservation status: ICMBio (2018): CR A2acd; IUCN (2019): CR A2cd.

Comments: MZUSP 8252 was originally labeled and identified as Cebus olivaceus nigrivittatus (Wagner, 1848) by C.O.C. Vieira. However, it was considered as C. (Cebus) kaapori by Silva Jr. (2001). Furthermore, Silva Jr. et al. (2010) reported that the specimen was acquired at a street fair in Belém and the original locality, indicated as Bragança, is doubtful.
Cebus (Cebus) unicolor Spix, 1823

Common names: caiarara, caiara (Port.); Spix's white-fronted capuchin (Eng.).

Records (2 localities and 2 specimens): Aruã, Rio Arapiuns: MZUSP 5133 (skin and skull; female); Sumaúma, Rio Tapajós: 7175 (skin and skull; female).

Conservation status: ICMBio (2018): LC; IUCN (2019): LC [as a synonym of Cebus albifrons (Humboldt, 1812)].

Comments: Silva Jr. (2001) did not recognize C. unicolor as a distinct species, treating it as a junior synonym of C. albifrons. In his revision, Silva Jr. (2001) identified MZUSP 5133 as C. apella (Linnaeus, 1758) and MZUSP 7175 as $C$. albifrons, following the identification on the labels by C.O.C. Vieira. Here we follow Mittermeier et al. (2013) in recognizing $C$. unicolor as a valid species. We identified both MZUSP 5133 and 7175 as C. unicolor.

\section{Subgenus Sapajus Kerr, 1792}

Cebus (Sapajus) apella (Linnaeus, 1758)

Common names: macaco-prego (Port.); tufted capuchin (Eng.).

Records (26 localities and 113 specimens): Aruã, Rio Arapiuns: MZUSP 5674 (skin and skull; male), 5675 (skin and skull; female); Barreira, Rio Tapajós: 19562 (skin and skull; female); Belém: 24250 (skull; unknown sex); Boim: 4291 (skin and skull; male); Boiçu: 5126 (skin and skull; female), 5134 (skin and skull; male); Bom Jardim, Rio Amazonas: 5128 (skin and skull; male), 5132 (skin and skull; male); Capim, BR-010, km 93: 8920 (skin and skull; male); Brasília Legal, Rio Tapajós: 19561 (skin and skull; male); Igarapé Bravo, Rio Amazonas: 5114 (skin; male), 5115 (skin and skull; male), 5116-5117 (skin and skull; female), 10546 (skull; male); Cachoeira do Espelho, Rio Xingu: 21325 (skin and skull; male), 22794 (skeleton; unknown sex); Caxiricatuba, Rio Tapajós: 5118 (skin and skull; female), 5119 (skin; female), 5120-5121 (skin and skull; male), 5122-5123 (skin; male), 5752-5753 (skin and skull; male), 10535 (skull; female), 10537 (skull; male), 10540-10541

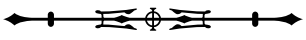


(skull; male), 19560 (skin; male); Curral Grande: 3636 (skin and skull; female); Fordlândia: 19564 (skin and skull; male), 19565 (skin and skull; female), 19566 (skin and skull; male), 19567 (skin and skull; female), 19568-19573 (skin and skull; male), 19574 (skin and skull; female), 19575-19577 (skin and skull; male), 19578 (skin and skull; female), 19579 (skin and skull; male), 19580 (skin and skull; female), 19581 (skin and skull; male), 19582 (skin and skull; female), 19583-19585 (skin and skull; male), 19586 (skin and skull; unknown sex), 19587-19588 (skin and skull; male), 19589 (skin and skull; female), 19590-19593 (skin and skull; male), 19594-19595 (skin and skull; female), 19596 (skin and skull; male), 19597-19599 (skin and skull; female), 19645 (skeleton; female), 19646 (skull; female); Ilha de Nova Olinda, Rio Tapajós: 24252 (skull; unknown sex); Itupiranga, Rio Tocantins: 19617 (skin and skull; male); Largo do Souza, Rio Iriri: 25446 (skin, skull and skeleton; male); Monte Cristo, Rio Tapajós: 19563 (skin and skull; female); Paissandu, Igarapé Bom Jardim: 8956 (skin and skull; female), 8957-8959 (skin and skull; male); Piquiatuba, Rio Tapajós: 10503 (skull; female); Rio Bacajá (mouth): 25451 (skin, skull and skeleton; male), 25452 (skin and skull; male); Rio Curuá (mouth): 5127 (skin; unknown sex), 5129 (skin and skull; male), 5130 (skin and skull; female), 5131 (skin; female), 5464 (skin; female), 5466 (skin; female), 10499 (skull; female), 10536 (skull; male), 10538 (skull; female), 10544 (skull; female); Rio Pucuruí, tributary of Rio Tocantins: 13482 (skin and skull; unknown sex); Santarém, Fazenda Maruá: 3633-3634 (skin; male); Santa Rosa, Ilha de Urucurituba: 19602-19603 (skin and skull; female); Santo Antônio, Rio Tocantins: 13480 (skin and skull; male); Urucurituba, Rio Tapajós: 19600-19601 (skin and skull; male), 19604-19606 (skin and skull; male), 19607-19608 (skin and skull; female), 19609 (skin and skull; male), 19610 (skin and skull; female), 19611-19612 (skin and skull; male), 19613 (skin and skull; female), 19614 (skin and skull; male), 19615 (skull and skeleton; female), 19616 (skull and skeleton; male), 19644 (skin and skull; female).
Conservation status: ICMBio (2018): LC; IUCN (2019): LC.

Subfamily Saimiriinae Miller, 1912

Genus Saimiri Voigt, 1831

Saimiri collinsi Osgood, 1916

Common names: macaco-de-cheiro, mico-de-cheiro, macaco-mão-de-ouro (Port.); Collins' squirrel monkey (Eng.).

Records (15 localities and 105 specimens): Belém: MZUSP 19137 (skin and skull; female), 19138-19140 (skin; female); Bom Jardim, Rio Amazonas: 5517 (skin and skull; male), 5519 (skin and skull; female), 5520-5521 (skin and skull; male); Capim, BR-010, km 93: 8921 (skin and skull; male), 8922 (skin and skull; female); Cachoeira do Espelho, Rio Xingu: 25435 (skin, skull and skeleton; male); Cametá: 5531 (skin and skull; male); Caxiricatuba, Rio Tapajós: 5523 (skin and skull; male), 5525-5526 (skin and skull; male), 5527 (skin and skull; female), 5528 (skin; unknown sex), 5529 (skin and skull; male), 5530 (skin and skull; unknown sex), 10515 (skull; female); Curral Grande: 3616 (skull; unknown sex), 3618 (skull; male), 3619 (skull; female), 3620 (skin and skull; female); Fordlândia: 10101-10102 (skin and skull; female), 19142 (skin and skull; female), 19143-19144 (skin and skull; male), 19145 (skin and skull; female), 19146-19150 (skin and skull; male), 19151-19153 (skin and skull; female), 19711-19714 (skin and skull; male), 19715 (skin; female), 19717 (skull and skeleton; female), 19718-19719 (skull and skeleton; male), 19722 (skull; unknown sex), 19723 (skin; male), 19724-19725 (skin and skull; male); Igarapé Taperebá, Ilha de Marajó: 8677 (skin and skull; female), 8678 (skin and skeleton; male), 19704 19705 (skull; male); Itapoama, Rio Tapajós: 10100 (skin and skull; female); Monte Cristo, Rio Tapajós: 3613-3614 (skin and skull; male); Posto DNERu (Departamento Nacional de Endemias Rurais), Rio Tocantins: 19709 (skin; male); Posto DNERu (Departamento Nacional de Endemias Rurais), Rio Tracajuba: 19710 (skin and skull; unknown 
sex); Piquiatuba, Rio Tapajós: 10531 (skull; female); $\underline{\text { Rio }}$ Bacajá (mouth): 25436-25438 (skin, skull and skeleton; male); Santo Antônio, Rio Tocantins: 13473 (skin and skull; unknown sex); Taperinha: 3615 (skin and skull; female).

Conservation status: ICMBio (2018): LC; IUCN (2019): LC [as a synonym of S. sciureus (Linnaeus, 1758)].

Comments: MZUSP 5521 from Bom Jardim has the same catalog number as a specimen of Saimiri sciureus from Boiuçu.

\section{Saimiri sciureus (Linnaeus, 1758)}

Common names: macaco-de-cheiro, mico-de-cheiro, macaco-mão-de-ouro (Port.); Guianan squirrel monkey, common squirrel monkey (Eng.).

Records (6 localities and 17 specimens): Boiuçu: MZUSP 5219 (skin and skull; male), 5220 (skin and skull; female), 5221 (skin and skull; male), 5224 (skin; male), 5225 (skin and skull; female), 5226 (skin and skull; male), 5227 (skin and skull; female); Igarapé Bravo, Rio Amazonas: 5222 (skin and skull; female), 5523 (skin and skull; female); Igarapé Piaba: 4315 (skin and skull; male); Jaguara: 8899 (skin and skull; male), 8900-8901 (skin and skull; female), 8902 (skin and skull; male); Lago Paru, Rio Trombetas: 19135 (skin and skull; female), 19141 (skin and skull; male); Paissandu, Igarapé Bom Jardim: 8955 (skin and skull; male).

Conservation status: ICMBio (2018): LC; IUCN (2019): LC.

Comments: The MZUSP 5521 from Boiuçu has the same catalog number as a specimen of Saimiri collinsi from Bom Jardim.

\section{Saimiri sp.}

Common names: macaco-de-cheiro, mico-de-cheiro, macaco-mão-de-ouro (Port.); squirrel monkey (Eng.).

Records (Unknown locality and 1 specimen): MZUSP 6786 (skin and skull; male).

Conservation status: not applicable.

Comments: identification remains as indeterminate due to the lack of detailed information regarding this specimen. No precise collection locality provided. The specimen is an old skin, which lost its original coloration, an important diagnostic character (Mercês et al., 2015).

Family Aotidae Elliot, 1913

Genus Aotus Illiger, 1811

Aotus infulatus (Kuhl, 1920)

Common names: macaco-da-noite, macaco-danoite-de-pescoço-vermelho (Port.); feline night monkey (Eng.).

Records (8 localities and 38 specimens): BR-010, km 92: MZUSP 10468 (skin and skull; female); Cachoeira do Espelho, Rio Xingu: 21326 (skin, skull and skeleton; male); Caxiricatuba, Rio Tapajós: 5046 (skin and skull; male); Fordlândia: 10156 (skin and skull; male), 10157 (skin and skull; female), 11513-11515 (skin and skull; female), 11516 (skin and skull; male), 11517 (skin and skull; female), 11518 (skin and skull; male), 11519-11520 (skin and skull; female), 11521-11523 (skin and skull; male), 11524-11527 (skin and skull; female), 11528 (skin and skull; male), 11530 (skull and skeleton; female), 11532 (skull and skeleton; unknown sex), 11533 (skull and skeleton; female); Largo do Souza, Rio Iriri: 25439 (skin and skull; female), 25440 (skin and skull; male); Monte Cristo, Rio Tapajós: 11504 (skin and skull; female), 11505-11506 (skin, skull and skeleton; female), 11507 (skin and skull; female), 11508 (skin, skull and skeleton; female), 11509 (skin and skull; male), 11510-11511 (skin, skull and skeleton; female), 11512 (skin and skull; female); Piquiatuba, Rio Tapajós: 5045 (skin and skull; female); Santo Antônio, Rio Tocantins: 13477 (skin and skull; male).

Conservation status: ICMBio (2018): LC; IUCN (2019): NT [as Aotus azarae infulatus (Kuhl, 1820)]. The recent taxonomic changes (see Comments) were not included in the latest conservation assessments by ICMBio (2018) and IUCN (2019). Therefore, this species was classified by these agencies as Aotus azarae infulatus.

Comments: Hershkovitz (1983) recognized Aotus infulatus as afullspecies, butRylandsetal.(2000), Groves(2001) 
and Fernandez-Duque et al. (2013) classified it as a subspecies of Aotus azarae. However, Paglia et al. (2012) followed the opinion of Hershkovitz (1983).

Family Pitheciidae Mivart, 1865

Subfamily Callicebinae Pocock, 1925

Genus Callicebus Thomas, 1903

Subgenus Plecturocebus Byrne, Rylands, Carneiro, LynchAlfaro, Bertuol, da Silva, Messias, Groves, Mittermeier, Farias, Hrbek, Schneider, Sampaio \& Boubli, 2016 Callicebus (Plecturocebus) hoffmannsi (Thomas, 1908)

Common names: guigó, sauá, zogue-zogue (Port.); Hoffmanns's titi (Eng.).

Records (6 localities and 20 specimens): Aruã, Rio Arapiúns: MZUSP 5091 (skin and skull; male); Brasilia Legal, Rio Tapajós: 11715 (skin and skull; male), 11721 (skin and skull; female), 11726 (skin and skull; male); Fordlândia: 11731 (skin and skull; female), 11839 (skin and skull; unknown sex); Itaituba: 3574 (skull; female), 3575 (skin and skull; female), 3576 (skin and skull; male); Sumaúma, Rio Tapajós: 11741 (skin and skull; female), 11745 (skin and skull; female); Urucurituba, Rio Tapajós: 19534 (skull; unknown sex); 10154-10155 (skin and skull; female), 11743 (skin and skull; female), 11815 (skin and skull; female), 11833 (skin and skull; male), 11834 (skin and skull; female), 11835-11836 (skin and skull; male).

Conservation status: ICMBio (2018): LC; IUCN (2019): LC.

Comments: according to Hershkovitz (1990), this species does not occur on the east bank of Rio Tapajós. Therefore, the two specimens from Fordlândia, a district located on the east bank of the river, are probably mislabeled or had been transferred to this bank in an oxbow cutoff (Hershkovitz, 1990).

Callicebus (Plecturocebus) moloch (Hoffmannsegg, 1807)

Common names: zogue-zogue, sauá-de-barrigavermelha, sauá-moreno (Port.); red-bellied titi, dusky titi, red-bellied titi (Eng.).
Records (14 localities and 73 specimens): Bom lardim, Rio Amazonas: MZUSP 5198 (skin; female); 5200 (skin and skull; female); Cachimbo: 8062 (skin and skull; male); Caxiricatuba, Rio Tapajós: 5143 (skin and skull; male), 5144 (skin and skull; female), 5146 (skin and skull; female), 5147 (skull; female), 5148 (skull; male), 5149 (skull; female), 5150-5151 (skull; male), 5152 (skull; female), 5157 (skull; female), 5159 (skin and skull; male), 5165 (skin and skull; male), 5166 (skin and skull; female), 5167 (skin and skull; male), 5169 (skin and skull; female), 24735 (skin and skull; male); Fordlândia: 10151 (skin and skull; female), 10153 (skin and skull), 11716-11718 (skin and skull; male), 11719-11720 (skin and skull; female), 11723 (skin and skull; female), 11724 (skin and skull; male), 11725 (skin and skull; female), 11727 (skin and skull; female), 11728 (skin; female), 11729 (skin and skull; female), 11730 (skin and skull; male), 11732 (skin and skull; male), 11733 (skin and skull; female), 11734 (skin and skull; male), 11735 (skin and skull; female), 11736 (skin and skull; male), 11737 (skin and skull; female), 11738-11739 (skin and skull; male), 11740 (skin and skull; female), 11742 (skin and skull; female), 11744 (skin and skull; female), 11813-11814 (skin and skull; female), 11816 (skin and skull; female), 11837 (skin; male), 11838 (skin and skull; male), 11840 (skin and skull; female), 11841 (skin; female), 19690 (skull; female); Itaituba: 3566 (skin and skull; male); Itapoama, Rio Tapajós: 10152 (skin and skull; male); Monte Cristo, Rio Tapajós: 3567 (skin and skull; male), 3568 (skin; female); 3569 (skin and skull; female), 11817 (skin and skull, male); Piquiatuba, Rio Tapajós: 5142 (skin and skull; female), 5153 (skin; male), 5155 (skin; female), 5156 (skin and skull; female), 5158 (skin and skull; female), 5160 (skin and skull; male); Rio Bacajá (mouth): 25444 (skin and skull; female), 25445 (skin and skull; male); Rio Curuá (mouth): 5196-5197 (skin and skull; female), 5202 (skin and skull; female); Santana do Araguaia, Fazenda Fartura: 35406 (skin; female); Santarém, Fazenda Marucu: 3571 (skin and skull; female), 3572 (skin and skull; male); Santo Antônio, Rio Tocantins: 13472 (skin and skull; unknown sex); Taperinha: 3570 (skin and skull; male). 
Conservation status: ICMBio (2018): LC; IUCN (2019): LC.

Callicebus (Plecturocebus) vieirai (Gualda-Barros, Nascimento \& Amaral, 2012)

Common names: guigó-de-vieira, sauá-de-vieira, zogue-zogue-de-vieira (Port.); Vieira's titi (Eng.).

Records (1 locality and 3 specimens): Largo do Souza, Rio Iriri: MZUSP 25441 (skin and skull; female), 25442-25443 (skin and skull; male) [paratypes].

Conservation status: ICMBio (2018): DD; IUCN (2019): DD.

Comments: this species was described based on specimens held in the MZUSP since 1997. Gualda-Barros et al. (2012) named the species after Dr. Octaviano da Cunha Vieira, former Curator of the Mammal Collection of the MZUSP from 1941 to 1958.

Subfamily Pitheciinae Mivart, 1865

Genus Chiropotes Lesson, 1840

Chiropotes albinasus (I. Geoffroy \& Deville, 1848)

Common names: cuxiú-de-nariz-vermelho (Port.); red-nosed bearded saki, red-nosed saki, white-nosed bearded saki, white-nosed saki (Eng.).

Records (8 localities and 31 specimens): Aruã, Rio Arapiuns: MZUSP 5304 (skin and skull; female), 5305 (skin and skull; male), 5307 (skin; male), 5309 (skin and skull; male), 5310 (skin and skull; female), 5313 (skin and skull; female); Barreira, Rio Tapajós: 19653 (skin; male); Cachimbo: 8008 (skin; female), 8009 (skin and skull; female), 8069 (skin and skull; female); Caxiricatuba, Rio Tapajós: 5311-5312 (skin and skull; female); Fordlândia: 12885 (skin and skull; female), 12886 (skin; female), 19660 (skin and skull; female), 19661-19662 (skin and skull; male), 19664-19667 (skin and skull; female), 19668 (skin; male); Monte Cristo, Rio Tapajós: 3626 (skin and skull; male), 19654 (skin, skull and skeleton; female), 19655-19656 (skin, skull and skeleton; male), 19657-19658 (skin and skull; female), 19659 (skin, skull and skeleton; male); Piquiatuba, Rio Tapajós: 5308 (skin and skull; female); Sumaúma, Rio Tapajós: 19663 (skin and skull; female).

Conservation status: ICMBio (2018): NT; IUCN (2019): EN A3cd.

\section{Chiropotes sagulatus (Trail, 1821)}

Common names: cuxiú-de-humboldt (Port.); Guianan bearded saki (Eng.).

Records (2 localities and 2 specimens): $\underline{\text { Cachoeira }}$ da Porteira, Rio Nhamundá: MZUSP 13632 (skull; male); Oriximiná: 19669 (skin, skull and skeleton; female).

Conservation status: ICMBio (2018): LC; IUCN (2019): NA.

Chiropotes satanas (Hoffmannsegg, 1807)

Common names: cuxiú-preto (Port.); black-bearded saki (Eng.).

Records (1 locality and 8 specimens): Capim, BR010, km 93: MZUSP 8912-8913 (skin and skull; female), 8914-8915 (skin and skull; male), 8916-8917 (skin and skull; female), 8918 (skin, skull and skeleton; female), 8919 (skin and sull; unknown sex).

Conservation status: ICMBio (2018): CR A2cd; IUCN (2019): CR A2c+3c.

\section{Chiropotes utahicki Hershkovitz, 1985}

Common names: cuxiú-de-uta-hick (Port.); Uta Hick's bearded saki (Eng.).

Records (4 localities and 5 specimens): Cachoeira do Espelho, Rio Xingu: MZUSP 21323 (skin and skeleton; female), 21324 (skin and skeleton; male); Igarapé Águas da Saúde, Rio Tocantins: 23484 (skin and skull; male); Itupiranga, Rio Tocantins: 13523 (skin; male); Remansinho, Rio Tocantins: 23485 (skin and skull; female).

Conservation status: ICMBio (2018): VU A4cd; IUCN (2019): EN A3cd.

Comments: the specimen MZUSP 13523 was identified as Chiropotes satanas satanas by Philip Hershkovitz 
in 1987, when he visited the MZUSP. However, in his previous work (Hershkovitz, 1985) he had identified the same specimen as C. s. utahicki. The pelage characters of specimen MZUSP 13523 have allowed us to identify it as Chiropotes utahicki.

\section{Genus Pithecia Desmarest, 1804}

Pithecia irrorata Gray, 1843

Common names: parauacu, macaco-velho, macacocabeludo (Port.); Gray's bald-faced saki (Eng.).

Records (2 localities and 2 specimens): Aruã, Rio Arapiuns: MZUSP 5549 (skin and skull; male) [Paratype of Pithecia mittermeieri Marsh, 2014]; Santarém, Fazenda Mararu, Rio Tapajós: 3632 (skin and skull; female).

Conservation status: ICMBio (2018): DD (as Pithecia irrorata irrorata); IUCN (2019): DD.

Comments: Hershkovitz (1987) recognized two subspecies for Pithecia irrorata: P. i. irrorata (Gray, 1843) and $P$. i. vanzolinii Hershkovitz, 1987. Subsequently Marsh (2014) raised these subspecies to species level and additionally proposed three putative new species from P. irrorata: P. mittermeieri, P. pissinattii Marsh, 2014 and P. rylandsi Marsh, 2014. However, Serrano-Villavicencio et al. (2019) concluded that these new putative species are not distinguished from each other and from $P$. irrorata, considering them junior synonyms of the latter.

\section{Pithecia pithecia (Linnaeus, 1766)}

Common names: parauacu, parauacu-de-carabranca, macaco-velho, macaco-cabeludo (Port.); whitefaced saki (Eng.).

Records (3 localities and 18 specimens): Boiuçu: MZUSP 5580 (skin and skull; male), 5582 (skin and skull; male), 5584-5585 (skin and skull; male), 5587 (skin and skull; female), 5591 (skin and skull; female), 5592 (skin and skull; male); Igarapé Bravo, Rio Amazonas: 5581 (skin and skull; male), 5583 (skin and skull; male), 5586 (skin and skull; male), 5588 (skin and skull; female), 5589 (skin and skull; male), 5590 (skin and skull; female); Óbidos: 3621 (skin and skull; male), 3622-3623 (skin and skull; female), 3624-3625 (skin and skull; male).

Conservation status: ICMBio (2018): LC; IUCN (2019): LC.

Comments: two subspecies are traditionally recognized, P. p. pithecia (Linnaeus, 1766) and P. p. chrysocephala (I. Geoffroy, 1850). Hershkovitz (1987) identified specimens from Pará as $P$. p. crysocephala, but subsequent studies (Silva Jr. et al., 2013) suggested that this taxon it is restricted to the Amazonas state (NegroNhamundá interfluvium), while $P$. p. pithecia is present in Pará (according to Hershkovitz, P. p. pithecia would present in the Guianas). Moreover, there is evidence of the existence of intermediate morphotypes in the region between the Rio Nhamundá and Rio Jari, supporting the recognition of subspecies (Silva Jr. et al., 2013). On the other hand, Marsh (2014) elevated these two subspecies to full species status. Here we follow Silva Jr. et al. (2013).

Family Atelidae Gray, 1825

Subfamily Alouattinae Trouessart, 1897

Genus Alouatta Lacépède, 1799

Alouatta belzebul (Linnaeus, 1766)

Common names: bugio-de-mãos-vermelhas, guaribade-mãos-vermelhas, bugio-de-mãos-ruivas, guariba-demãos-ruivas (Port.); red-handed howler (Eng.).

Records (8 localities and 22 specimens): Belém: MZUSP 19004 (skin and skull; male); Capim, BR-010, km 93: 8910 (skin, skull and hyoid; female), 8911 (skin and skull; female), 8936 (skin, skull and hyoid; female), 8937 (skin and skull; female), 8938 (skin and skull; male), 8939 (skull; male); Cametá, Rio Tocantins: 5256 (skin; female), 5405 (skin; male), 5406 (skin and skull; male), 5407 (skin, skull and hyoid; male), 5408 (skin, skull; female); 10489 (skull; female), 26831 (skull; male); Cachoeira do Espelho, Rio Xingu: 20927 (skin and skull; male), 20928 (skin; female), 20929 (skin and skull; male); Largo do Souza, Rio Iriri: 25448 (skin, skull and skeleton; male); Rio Amazonas: 
19511 (fetus in formalin); Rio Bacajá (mouth): 25449 (skin, skull and hyoid; male), 25450 (skull, hyoid and skeleton; female); Santo Antônio, Rio Tocantins: 13483 (skin, skull and hyoid; female).

Conservation status: ICMBio (2018): VU A2cd; IUCN (2019): VU A2cd.

\section{Alouatta discolor (Spix, 1823)}

Common names: bugio-de-mãos-vermelhas, guaribade-mãos-vermelhas, bugio-de-mãos-ruivas, guariba-demãos-ruivas (Port.); Spix red-handed howler (Eng.).

Records (10 localities and 68 specimens): Barreira: MZUSP 18972 (skin and skull; female); Boiuçú: 5472 (skin; male); Bom Jardim, Rio Amazonas: 5409-5410 (skin and skull; female), 5411 (skull; male), 5568 (skin and skull; male), 5572 (skin; female), 5573 (skin and skull; male), 5747 (skin and skull; female), 5748 (skin; female), 7110 (skull; female), 18996 (skull; male), 24833 (skin and skull; male); Caxiricatuba, Rio Tapajós: 5328 (skin and skull; female), 5565 (skin and skull; male), 5566 (skin, skull and hyoid; male), 5567 (skin and skull; male), 5570 (skin and skull; female), 6022 (skull; male), 10563 (skull; male), 10565 (skull; male), 18997 (skin; unknown sex), 19032 (skin; male), 19118 (skull; male); Fordlândia: 18966 (skin and skull; female), 18967 (skin, skull and hyoid; male), 18968-18970 (skin and skull; female), 18971 (skin, skull and hyoid; female), 18973-18974 (skin, skull and hyoid; female), 18975 (skin and skull; male), 18976 (skin, skull and hyoid; male), 18977 (skin, skull and hyoid; female), 18978 (skin and skull; female), 18979 (skin, skull and hyoid; male), 18981 (skin, skull and hyoid; female), 18982 (skin and skull; male), 18983 (skin, skull and hyoid; male), 18984 (skin, skull and hyoid; female), 18985 (skin, skull and hyoid; male), 18986 (skin, skull and hyoid; female), 18987 (skin, skull and hyoid; male), 18988 (skin and skull; male), 18989 (skin, skull and hyoid; female), 18991 (skin, skull and hyoid; male), 18992 (skin, skull and hyoid; female), 18993 (skin, skull and hyoid; male), 18994-18995 (skin, skull and hyoid; female), 18998 (skin; female), 18999-19000 (skin, skull and hyoid; male); Monte Cristo, Rio Tapajós: 3645 (skin; skin, skull and hyoid; female); Piquiatuba, Rio Tapajós: 5329-5330 (skin and skull; male), 5333 (skin and skull; male), 5574 (skin and skull; male), 10495 (skull and hyoid; male); Rio Tapajós: 3644 (skin, skull and hyoid; male), 24256 (skull and hyoid; male); Serra do Cachimbo: 8063 (skin, skull and hyoid; male), 8066 (skin, skull and hyoid; male), 8067 (skull; male), 8068 (skin; female), 8071 (skin and skull; female); Taperinha: 18935 (skin, skull and hyoid; male).

Conservation status: ICMBio (2018): VU A4cd; IUCN (2019): VU A2c.

\section{Alouatta macconnelli (Linnaeus, 1766)}

Common names: bugio-vermelho, guariba-vermelho (Port.); Guianan red howler (Eng.).

Records (8 localities and 33 specimens): Boiuçu: MZUSP 5095 (skin and skull; female), 5096 (skin, skull and hyoid; male), 5473 (skin and skull; male), 5474 (skin and skull; male), 19088 (skull and hyoid; male); Igarapé Bravo, Rio Amazonas: 5094 (skin and skull; male), 5435 (skin; female), 5470 (skin and skull; male), 5471 (skin and skull; female), 5476 (skin and skull; female), 5478 (skin and skull; male), 5480 (skin and skull; female), 5481 (skin and skull; male), 7113 (skull; female), 10496 (skull; male), 19123 (skull; female); Faro: 9955 (skin, skull and hyoid; female), 9956 (skin, skull and hyoid; male); laguara: 19121 (skull and hyoid; male); Óbidos: 3637 (skin and skull; male), 3638-3639 (skin and skull; female), 3640 (skin and skull; male), 19086 (skull; male); Paissandu, Igarapé Bom Jardim: 9949 (skin; male), 9950 (skin; unknown sex), 9951-9952 (skin, skull and hyoid; male), 9953-9954 (skin and skull; male), 9957-9958 (skin, skull and hyoid; female), 19085 (skull and skeleton; male).

Conservation status: ICMBio (2018): LC; IUCN (2019): LC

\section{Alouatta nigerrima Lönnberg, 1941}

Common names: bugio-preto, guariba-preto (Port.); Amazon black howler (Eng.).

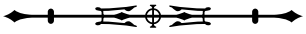


Records (6 localities and 7 specimens): Itaituba: MZUSP 3646 (skin, skull and hyoid; male); Samaúma: MZUSP: 19003 (skin, skull and skeleton; male); Óbidos: 3643 (skull; male); Parque Nacional da Amazônia, Igarapé do Cotovelo: 24603 (skull; unknown sex); Parque Nacional da Amazônia, Uruá: 19119 (skull and skeleton; male); Urucurituba, Rio Tapajós: 19001 (skin; male), 19002 (skin, skull and hyoid; female).

Conservation status: ICMBio (2018): LC; IUCN (2019): LC.

Subfamily Atelinae Gray, 1825

Genus Ateles É. Geoffroy, 1806

Ateles chamek (Humboldt, 1812)

Common names: macaco-aranha-de-cara-preta, coatá-de-cara-preta (Port.); Peruvian spider monkey (Eng.).

Records (2 localities and 2 specimens): Barreira, Rio Tapajós: MZUSP 19326 (skin and skull; male); Urucurituba, Rio Tapajós: 19543 (skeleton; female).

Conservation status: ICMBio (2018): VU A4cd; IUCN (2019): EN A2cd.

\section{Ateles marginatus É. Geoffroy, 1809}

Common names: macaco-aranha-de-cara-branca, coatá-de-cara-branca (Port.); white-cheeked spider monkey (Eng.).

Records (9 localities and 47 specimens): Cachimbo: MZUSP 8064 (skull; male), 8070 (skull; unknown sex), 19331 (skin; female), 19332 (skin; unknown sex); Caxiricatuba, Rio Tapajós: 5281-5282 (skin and skull; female), 5284-5285 (skin and skull; female), 5287 (skin and skull; female), 5603 (skin; male), 5604 (skin; unknown sex), 5605 (skin and skull; female); Fordlândia: 10158 (skin and skull; female), 19313 (skin and skull; male), 19314-19316 (skin and skull; female), 19317-19322 (skin and skull; male), 19323 (skin and skull; female), 19324 (skin and skull; male), 19325 (skin and skull; female), 19327 (skin and skull; female), 19329 (skin and skull; female), 19330 (skin and skull; male); Piquiatuba, Rio Tapajós: 5279 (skin and skull; female), 5286 (skin and skull; female), 5606 (skin and skull; female), 5607 (skin and skull; male), 7104-7105 (skull; female), 19188 (skin; female); Rio Curuá do Sul (mouth): 7101-7102 (skull; female), 19335 (skull; female); Rio Curuá-Una (mouth): 5288 (skin and skull; male), 5600 (skin and skull; female); Santarém: 19328 (skin and skull; female); Tapaiúna, Rio Tapajós: 10159 (skin and skull; female); Taperinha: 3565 (skin and skull; female).

Conservation status: ICMBio (2018): EN A4cd; IUCN (2019): EN A4cd.

Ateles paniscus (Linnaeus, 1758)

Common names: macaco-aranha-de-cara-vermelha, coatá-de-cara-vermelha (Port.); red-faced spider monkey, red-faced black spider monkey, Guiana spider monkey (Eng.).

Records (3 localities and 6 specimens): Igarapé Bravo, Rio Amazonas: MZUSP 5277 (skin and skull; male), 5278 (skull; female), 25777 (skin; female); Óbidos: 3641 3642 (skin and skull; female); Rio Cuminá-Miri (mouth): 19334 (skull; unknown sex).

Conservation status: ICMBio (2018): LC; IUCN (2019): VU A4cd.

Order Lagomorpha Brandt, 1855

Family Leporidae Fischer, 1817

\section{Genus Sylvilagus Gray, 1867}

Sylvilagus minensis Thomas, 1901

Common names: tapiti, coelho-do-mato (Port.); tapeti, Brazilian cottontail, forest cottontail (Eng.).

Records (3 localities and 3 specimens): Barreirinha, Rio Tapajós: MZUSP 26750 (skin and skull; male); Cachoeira do Espelho, Rio Xingu: 21304 (skin and skull; female); Fordlândia: 26751 (skin and skull; male).

Conservation status: ICMBio (2018): LC (as S. brasiliensis); IUCN (2019): NA. 
Comments: the taxonomy of Sylvilagus brasiliensis (Linnaeus, 1758) is undergoing profound changes, and some of the subspecies and synonyms are now treated as a full species (Ruedas, 2017; Ruedas et al., 2017). Tapetis found in the state of Pará are now classified as $S$. minensis (see Ruedas, 2017; Ruedas et al., 2017).

Order Rodentia Bowdich, 1821

Family Caviidae Fischer, 1817

Subfamily Hydrochoerinae gray, 1825

Genus Hydrochoerus Brisson, 1762

Hydrochoerus hydrochaeris (Linnaeus, 1766)

Common names: capivara (Port.); capybara (Eng.).

Records (1 locality and 1 specimen): Cachoeira do Espelho, Rio Xingu: MZUSP 20925 (skin and skull; male).

Conservation status: ICMBio (2018): LC; IUCN (2019): LC.

Family Cuniculidae Miller \& Gidley, 1918

\section{Genus Cuniculus Brisson, 1762}

Cuniculus paca (Linnaeus, 1766)

Common names: paca (Port.); lowland paca, spotted paca (Eng.).

Records (11 localities and 29 specimens): As Pedras, Rio Cuminá-Miri: MZUSP 25462 (skin and skull; male), 25463 (skin and skull; female), 25464 (skin and skull; male); Igarapé Bravo, Rio Amazonas: 5263 (skin and skull; female); Capim, BR-010, km 94: 9616 (skin and skull; male), 9617-9618 (skin and skull; female and fetus), 9619 (skull; female), 9620 (skull; male), 9621 (skull; unknown sex), 9622 (skull; female), 9623-9626 (skull; male); Cachoeira do Escalaço, Rio Xingu: 25457 (skin and skull; male); Cachoeira do Espelho, Rio Xingu: 21331 (skin and skull; female and embryo), 21335 (skull; male); llha de Nova Olinda, Rio Tapajós: 25466 (skull; unknown sex); Lago Jacaré, Rio Trombetas: 10709 (skin and skull; female), 10710 (skin and skull; female), 10711 (skin and skull; pregnant female), 10712 (skin and skull; male), 26840 (fetus of female 10709; in alcohol); Oriximiná, Açaizinho: 24919 (fetus in alcohol); Parque Nacional da Amazônia: 25465 (skull; unknown sex), 25467 (partial skeleton; unknown sex); Piquiatuba, Rio Tapajós: 5267 (skin and skull; female); Rio Curuá (mouth): 5265 (skin and skull; male).

Conservation status: ICMBio (2018): LC; IUCN (2019): LC.

Family Dasyproctidae Bonaparte, 1838

Genus Dasyprocta Illiger, 1811

Dasyprocta croconota Wagler, 1831

Common names: cutia (Port.); orange agouti (Eng.).

Records (9 localities and 67 specimens): Bom Jardim, Rio Amazonas: MZUSP 5373 (skin and skull; female), 5377 (skin and skull; female), 5378-5379 (skin and skull; male), 5384 (skin and skull; female); Cametá, Rio Tocantins: 5363 (skin; unknown sex), 5478-5479 (skin; male), 5475-5477 (skull; male), 25558 (skull; male), 25564 (skull; unknown sex), 25568 (skull; male); Caxiricatuba, Rio Tapajós: 5356 5357 (skin and skull; male), 5359-5360 (skin; female), 5361 (skin and skull; female), 5365 (skin and skull; male), 5366 (skin and skull; female), 5368 (skin and skull; unknown sex), 5371-5372 (skin and skull; female), 5374 (skin and skull; male), 5376 (skin; female), 5383 (skin and skull; male); Fordlândia: 10146-10147 (skin and skull; male), 10148 (skin and skull; female), 10149 (skin and skull; male), 25477 (skin and skull; female), 25478-25480 (skin and skull; male), 25481 (skin and skull; unknown sex), 25482-25483 (skin and skull; female), 25484-25487 (skin and skull; male), 25488 (skin and skull; female), 25489-25490 (skin and skull; male), 25491-25492 (skin and skull; female), 25534 (skin and skull; female), 25535 (skull and skeleton; female); Piquiatuba, Rio Tapajós: 5355 (skin and skull; female), 5358 (skin and skull; female), 5364 (skin and skull; male), 5367 (skin and skull; female), 5369 (skin and skull; female), 5381 (skin and skull; male), 5382 (skin and skull; male), 5438 (skin and skull; male); Rio Curuá (mouth): 5353 (skin and 
skull; female), 5354 (skin and skull; male), 5362 (skin and skull; female), 5380 (skin and skull; male), 25493 (skin and skull; male), 25559 (skin and skull; male), 25560 (skin and skull; male); Taperinha: 3789 (skin and skull; female); Urucurituba, Rio Tapajós: 25476 (skin and skull; female); Santarém: 3790 (skin; male); Santarém, Fazenda Marucu: 25530 (skin; male).

Conservation status: ICMBio (2018): LC; IUCN (2019): DD.

Dasyprocta leporina (Linnaeus, 1758)

Common names: cutia (Port.); red-rumped agouti (Eng.).

Records (6 localities and 10 specimens): Igarapé Bravo, Rio Amazonas: MZUSP 5324-5325 (skin and skull; female), 5331 (skin and skull; female); Cachoeira do Espelho, Rio Xingu: 20930 (skin and skull; male), 21332 (skin and skull; male); Gorotire: 25515 (skin; unknown sex); Lago Jacaré, Rio Trombetas: 10714 (skin and skull; female), 26742 (fetus of 10714); Óbidos: 3788 (skin and skull; unknown sex); Parque Nacional da Amazônia, Rio Tapajós: 25514 (skin and skull; unknown sex).

Conservation status: ICMBio (2018): LC; IUCN (2019): LC.

Comments: lack-Ximenes (1999) considered specimens south of the Rio Amazonas as D. aguti Linnaeus, 1766, while those in the north of this river and the Guianas were recognized as $D$. leporina.

\section{Dasyprocta prymnolopha Wagler, 1831}

Common names: cutia (Port.); black-rumped agouti (Eng.).

Records (3 localities and 10 specimens): Capim. BR-010, km 93: MZUSP 8943 (skull; unknown sex), 8944-8945 (skin and skull; male), 8946-8947 (skin and skull; female), 8948 (skin and skull; unknown sex), 8949 (skin and skull; male), 8952 (skin and skull; male); Belém: 8641 (skin; male); Paraná do Samaúma, Rio Tocantins: 25516 (skin and skull; unknown sex).
Conservation status: ICMBio (2018): LC; IUCN (2019): LC.

Genus Myoprocta Thomas, 1903

Myoprocta acouchy (Erxleben, 1777)

Common names: cutiara, cutia-de-rabo (Port.); red acouchi (Eng.).

Records (4 localities and 9 specimens): Igarapé Bravo, Rio Amazonas: MZUSP 4709 (skin and skull; female), 4821 (skin; female); Boiuçu: 4710 (skin and skull; skin and skull; female); Curuá, Lago Cuiteuá, Rio Amazonas: 4635 (skin and skull; female), 4832 (skin and skull; female); Óbidos: 3688 (skin and skull; female), 3689 (skin and skull; unknown sex), 3690 (skin and skull; male), 4204 (skin and skull; male).

Conservation status: ICMBio (2018): LC; IUCN (2019): LC.

Comments: two species of Myoprocta are recognized, the red acouchi $M$. acouchy, found in the Guianas and northern Brazil (north bank of the Rio Amazonas), and the green acouchi M. pratti Pocock, 1913, distributed in the western Amazon, from Venezuela and Colombia to northern Bolivia (Voss et al., 2001; Patton \& Emmons, 2015; Teta, 2019). lack-Ximenes (1999) identified the specimens distributed in the NegroTrombetas interfluvium as M. exilis (Wagler, 1831), while those found east of the Rio Trombetas as $M$. demararae (Tate, 1939), both considered junior synonyms of $M$. acouchy by other authors.

Family Erethizontidae Bonaparte, 1845

Genus Coendou Lacépède, 1799

Coendou nycthemera (Olfers, 1818)

Common names: ouriço-cacheiro, porco-espinho (Port.); Eastern Amazonian dwarf porcupine (Eng.).

Records (4 localities and 10 specimens): Belém: MZUSP 13519-13520 (skin and skull; male); BR-010, km 87-94: 25591 (skull; unknown sex); Cametá, Rio Tocantins: 
5031-5034 (skin and skull; unknown sex), 5036-5037 (skin and skull; unknown sex), 5038 (skin; female), 5039 (skin and skull; unknown sex); Caxiricatuba, Rio Tapajós: 5035 (skin and skull; female).

Conservation status: ICMBio (2018): LC; IUCN (2019): DD.

Coendou prehensilis (Linnaeus, 1758)

Common names: ouriço-cacheiro, porco-espinho (Port.); Brazilian porcupine (Eng.).

Records (5 localities and 8 specimens): Barreira, Rio Tapajós: MZUSP 25232 (skin and skull; female); Cachoeira do Espelho, Rio Xingu: 20931 (skin, skull and skeleton; unknown sex), 21302 (skin, skull and skeleton; male), 21303 (skin, skull and skeleton; female); Cametá, Rio Xingu: 5042 (skin and skull; male); Parque Nacional da Amazônia, Uruá, km 65: 25230 (partial skeleton; unknown sex), 25231 (skull; unknown sex); Santo Antônio, Rio Tocantins: 13486 (skin and skull; unknown sex).
Conservation status: ICMBio (2018): LC; IUCN (2019): LC

\section{SPECIES RECORDED FOR THE STATE OF PARÁ WITHOUT VOUCHER SPECIMENS IN THE MZUSP}

Table 1 contains the species of medium and large-sized mammals that have records in the literature for the state of Pará, but do not have voucher specimens deposited in the MZUSP.

\section{SAMPLING RICHNESS}

The MZUSP houses 1,910 specimens representing 79 species of mammals from Pará state. These species correspond to nine of the 10 orders recognized for the state (Percequillo \& Gregorin, 2019), emphasizing the importance of the MZUSP collection. However, this representativeness is not equal in terms of the number of specimens for each genus (Figure 1).

Table 1. List of medium and large-sized mammal species (scientific and popular names in Portuguese and English) recorded for the state of Pará, Brazil, but without voucher specimens deposited in the MZUSP. In the right column are the bibliographic sources of the species records. References: 1 = Andrade et al. (2018); 2 = Boubli et al. (2008); 3 = Brandão et al. (2015); $4=$ Duarte et al. (2012); 5 = Emin-Lima et al. (2010); 6 = Faria \& Melo (2017); 7 = Goeldi \& Hagmann (1904); 8 = González et al. (2010); 9 = Hrbek et al. (2014); 10 = Mendes-Oliveira et al. (2011); $11=$ Oliveira, L. et al. (2009); 12 = Pimenta \& Silva Jr. (2005); $13=$ Rossi et al. (2017); 14 = Siciliano et al. (2016); 15 = Silva Jr. et al. (2010); 16 = de Vivo (1991); 17 = Voss et al. (2001); $18=$ Voss et al. (2018); 19 = Wetzel et al. (2008)

(Continue)

\begin{tabular}{ccc}
\hline \multirow{2}{*}{ Taxa } & \multicolumn{2}{c}{ Common name } \\
\cline { 2 - 3 } References
\end{tabular}

\section{Didelphimorphia Gill, 1872}

\section{Didelphidae Gray, 1821}

Didelphis Linnaeus, 1758

D. imperfecta Mondolfi \& PérezHernàndez, 1984

Gambá, mucura, saruê, sarigueia

Guianan white-eared opossum

$3,6,13$

Philander Brisson 1762

P. canus (Osgood, 1913)

Cuíca-de-quatro-olhos

Gray four-eyed opossum

17

\section{Cingulata Illiger, 1811}

\section{Chlamyphoridae Bonaparte, 1850}

Cabassous McMurtrie, 1831

C. unicinctus (Linnaeus, 1758)

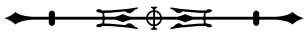

890 
Table 1. (Conclusion)

\begin{tabular}{ccc} 
Taxa & \multicolumn{2}{c}{ Common name } \\
\cline { 2 - 3 } & Portuguese & English \\
\hline
\end{tabular}

\section{Sirenia Illiger, 1811}

Trichechidae Gill, 1872

Trichechus Linnaeus, 1758

T. manatus (Linnaeus, 1758)

Peixe-boi-marinho

West Indian manatee

Carnivora Bowdich (1821)

Mustelidae Fischer, 1817

Lontra Gray, 1843

L. longicaudis (Olfers, 1818)

Lontra

Neotropical otter

5, 15

\section{Artiodactyla Owen, 1848}

\section{Cervidae Goldfuss, 1820}

Blastocerus Wagner, 1844

B. dichotomus (Illiger, 1815)

Cervo-do-pantanal, suaçuetê

Marsh deer

Odocoileus Rafinesque, 1832

O. virginianus (Zimmermann, 1780)

Veado-galheiro, cariacu

White-tailed deer

Ozotoceros Ameghino, 1891

O. bezoarticus (Linnaeus, 1758)

Veado-campeiro, veado-branco

Pampas deer

$7,8,15$

Iniidae Gray, 1846

Inia d'Orbigny, 1834

I. araguaiaensis Hrbek et al., 2014

Boto-do-araguaia

Araguian river dolphin

9,14

\section{Primates Linnaeus, 1758}

\section{Callitrichidae Thomas, 1903}

Mico Lesson, 1840

M. emiliae (Thomas, 1920)

Sagui-de-snethlage, mico-de-snethlage

Sauim

S. (S.) martinsi (Thomas, 1912)

Cebidae Bonaparte, 1831

Cebus Erxleben, 1777

C. (C.) olivaceus (Schomburgk, 1848)

\section{Atelidae Gray, 1825}

Lagothrix É. Geoffroy, 1812

Lagothrix cana (É. Geoffroy, 1812)

\section{Rodentia Bowdich, 1821}

\section{Erethizontidae Bonaparte, 1845}

Coendou Lacépède, 1799

C. melanurus (Wagner, 1842)
Ouriço-cacheiro
Black-tailed hairy dwarf porcupine
$1,12,16$

11

15

2

Peruvian wolly monkey

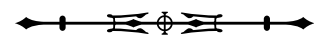




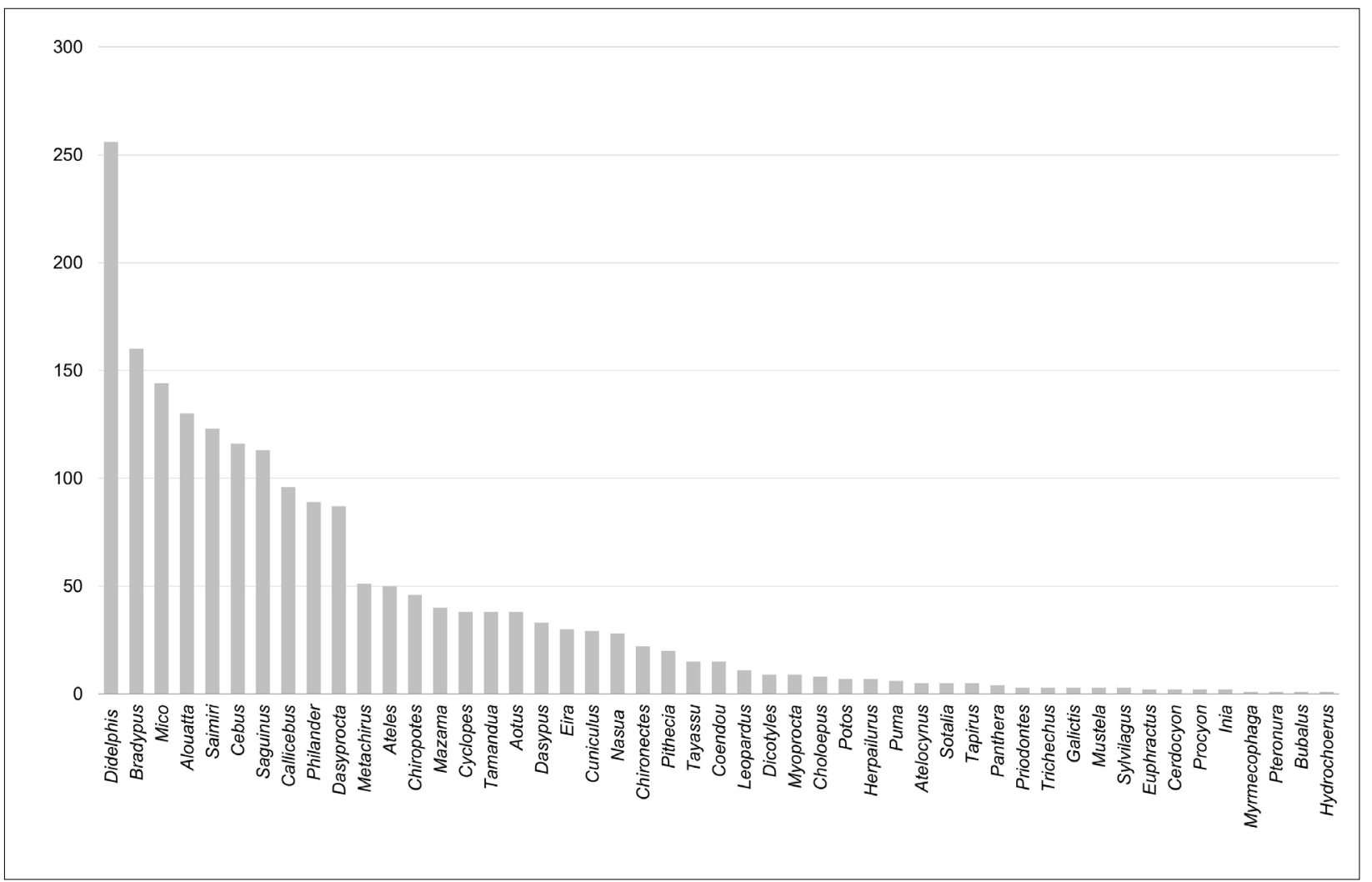

Figure 1. Number of specimens per genus collected in the state of Pará, Brazil, and housed in the Mammal Collection of the Museu de Zoologia da Universidade de São Paulo, SP, Brazil.

The most represented genus in the collection is Didelphis, with 216 specimens, corresponding to $13 \%$ of all specimens from Pará state. Bradypus and some primate genera (Mico, Alouatta, Saimiri, Cebus, and Saguinus), also have large number of specimens ( $>100$ ). On the other hand, $46 \%$ of the genera found in MZUSP are represented by less than 10 specimens, demonstrating a possible collection bias in favor of the first-mentioned taxa.

Regarding the geographical distribution of the samples (Figure 2), there are four areas of denser collection: (1) a large concentration in the west of the state, which encompasses the Lower Rio Tapajós, Lower Rio Trombetas, and the Rio Amazonas between the mouth of Rio Nhamundá and mouth of Rio Curuá-Una; (2) Lower Rio Xingu, between the mouth of Rio Iriri and the mouth of Rio Bacajá; (3) Rio Tocantins in the Tucuruí region; and
(4) the northeastern portion of Pará, which encompasses the mouth of the Rio Tocantins, Ilha de Marajó, and Belém municipality area. On the Tucuruí region, it is worth mentioning that many collection localities are currently submerged by a giant reservoir $\left(>2,400 \mathrm{~km}^{2}\right)$ caused by the Tucuruí Dam, which was completed in the mid-1980s (Goulding et al., 2003; Pinto, L., 2012).

On the other hand, there is a lack of specimen representation mainly in the central and southern regions of the state, as well as the region on the left bank of the Rio Amazonas. Most of the specimens were collected in forested areas of the Amazon biome, and only a few in Cerrado patches or Amazon-Cerrado transition areas, such as Serra do Cachimbo, Formiga, Canaã dos Carajás, Gorotire, and Santana do Araguaia. These large concentrations of collection points in certain areas of the 


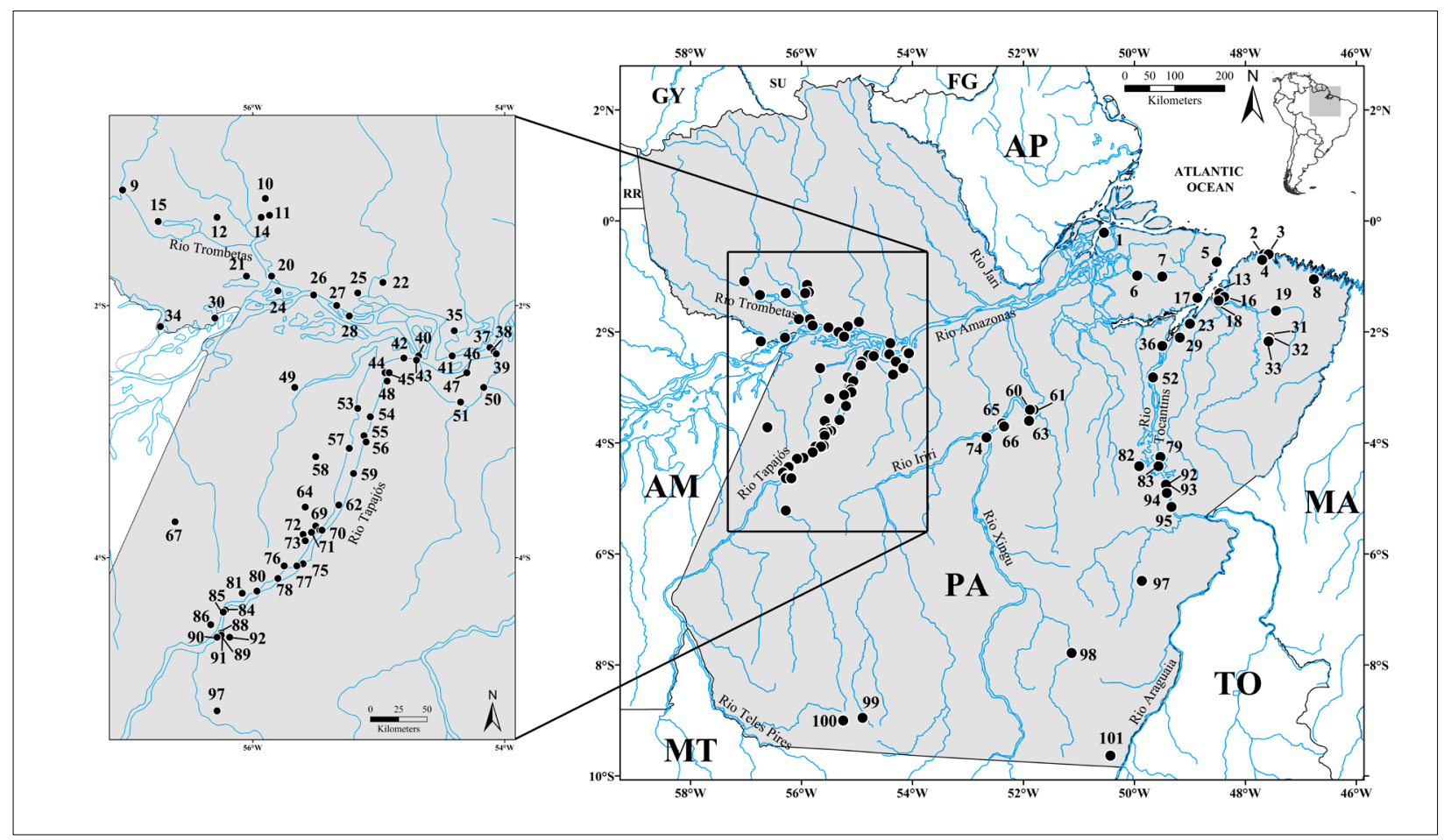

Figure 2. Collection localities (black dots) of the specimens of medium and large-sized mammals from Pará state (in gray) housed in the Mammal Collection of the Museu de Zoologia da Universidade de São Paulo, SP, Brazil. Numbers correspond to collection localities listed in the gazetteer (see Appendix 1). Legend: $A M=$ state of Amazonas, Brazil; AP = state of Amapá, Brazil; FG = French Guiana; GY = Guyana; MA = state of Maranhão, Brazil; MT = state of Mato Grosso, Brazil; PA = state of Pará, Brazil; RR = state of Roraima, Brazil; $\mathrm{SU}=$ Suriname; $\mathrm{TO}=$ state of Tocantins, Brazil.

state reflect the history of collection expeditions, which were conducted along major rivers and near municipalities or localities with a higher concentration of human population at the time [for example, see Pinto, O. (1945) who reported in detail the routes and collection localities of the MZUSP expeditions in the Amazon in the first half of the last century].

As pointed out by de Vivo et al. (2014), even the best museums in terms of geographical representation cannot provide, alone, sufficient data about the distribution of a single taxon. Therefore, for more comprehensive studies about mammals of Pará state, it is crucial to consult additional Mammalogy collections, such as Museu Paraense Emílio Goeldi, Belém, Pará state, and the Museu Nacionall Universidade Federal do Rio de Janeiro, Rio de Janeiro state. In this context, museum catalogs, such as Vieira $(1944,1945$,
1946, 1949, 1951, 1953a, 1953b, 1957), Ávila-Pires (1968), Napier (1976), Lawrence (1993), Fisher \& Ludwig (2014), Bezerra \& Bordallo (2018), and the present contribution, are important references for the mammal richness represented in scientific collections. For medium and large-sized mammals, especially, these catalogs should be considered as primary sources to found specimens, since they cannot be collected as it was in the first half of the 20th century (Pinto, O., 1945; Nascimento, 2014), and the number of samples housed in scientific collections are usually small (Rossi, 2000).

Among the species listed here, 24 are currently threatened (VU: 18; EN: 4; CR: 2, following the classification of ICMBio, 2018) according to the definitions proposed by Portaria MMA (Brasil, 2014, Art. $6^{\circ} \S 2^{\circ}$ ). One of the greatest threats for mammals in Brazil is habitat loss and fragmentation (Costa et al., 2005). The eastern, 
southern and southeastern state of Pará, for being insert in the arc of deforestation, suffers of a heavy human pressure, resulting in a few and sparsely forested areas surrounded by agricultural farms (Negrões et al., 2011; Aldrich et al., 2012). Additionally, medium and large-sized mammals are heavily affected by the hunting pressure in the remaining forests, even in the protected ones, resulting in population decline or local extinction (Costa et al. , 2005; Peres et al. , 2016). Two critically endangered species present in the MZUSP, Cebus (Cebus) kaapori and Chiropotes satanas, are examples of population reduction due to these threats. These primate species were originally distributed through the Belém area of endemism (ICMBio, 2018). In this area, deforestation has reached $76 \%$, remaining only few fragments of primary and secondary forest (Almeida \& Vieira, 2010), leading to the population decline of these two species to an estimated 80\% during the last 30-40 years (ICMBio, 2018).

In this scenario, the MZUSP, as well as other scientific collections, are of great importance to preserve samples of the biodiversity, especially of the threatened and extinct species. The relevance of scientific collections transcends time and space. Thus, MZUSP holds an important and priceless part of the Brazilian mammalogy that will be the legacy to be used by the next generations of scientists worldwide.

\section{CONCLUSIONS}

The present catalog demonstrates that most of the medium and large-sized mammal richness of Pará state is represented in the MZUSP. The majority of the preserved material was collected in a few areas of the state, leaving many areas unsampled. These results reflect the history of the collection over the years and allow the researcher to make projections of the main areas of study and possible important regions for sample collection. In this context, this catalog plays an important role in presenting the currently known biodiversity of medium and large-sized mammals of Pará, also acting as a primary source for systematics, ecological, conservation and biogeographic studies.

\section{ACKNOWLEDGMENTS}

We are grateful to Luís Fábio Silveira and Juliana GualdaBarros for permission to examine the specimens and the collection catalogs; José Eduardo Serrano-Villavicencio and Guilherme Siniciato Terra Garbino for valuable suggestions; Dione Seripierri for valuable effort in obtaining some important references; and Alexandra Bezerra for the invitation to participate in this special edition. Finally, we are also grateful to Ricardo Moratelli and one anonymous reviewer for critically commenting on earlier versions of this contribution. RLV is supported by Coordenação de Aperfeiçoamento de Pessoal de Nível Superior (CAPES).

\section{REFERENCES}

ACOSTA, L. E., G. S. T. GARBINO, G. M. GASPARINI \& R. P. DUTRA, 2020. Unraveling the nomenclatural puzzle of the collared and white-lipped peccaries (Mammalia, Cetertiodactyla, Tayassuidae). Zootaxa 4851(1): 60-80. DOI: https://doi. org/10.11646/zootaxa.4851.1.2

ALDRICH, S., R. WALKER, C. SIMMONS, M. CALDAS \& S. PERZ, 2012. Contentious land change in the Amazon's arc of deforestation. Annals of the Association of American Geographers 102(1): 103-128. DOI: https://doi.org/10.1080/0 0045608.2011 .620501

ALMEIDA, A. S. \& I. C. G. VIEIRA, 2010. Centro de endemismo Belém: status da vegetação remanescente e desafios para a conservação biológica e restauração Ecológica. Revista de Estudos Universitários 36(3): 95-111.

ALVAREZ, C. A., J. L. STAPE, P. C. SENTELHAS, J. L. M. GONÇALVES \& G. SPAROVEK, 2013. Köppen's climate classification map for Brazil. Meteorologische Zeitschrift 22(6): 711-728. DOI: https://doi.org/10.1127/0941-2948/2013/0507

ANDRADE, R. P., I. MOURTHE, V. SACCARDI \&E. J. HERNÁNDEZRUZ, 2018. Eastern extension of the geographic range of Mico emiliae. Acta Amazonica 48(3): 257-260. DOI: https://doi. org/10.1590/1809-4392201704392

ASHER, R. J. \& K. M. HELGEN, 2010. Nomenclature and placental mammal phylogeny. BMC Evolutionary Biology 10: 102. DOI: https://doi.org/10.1186/1471-2148-10-102.

ÁVILA-PIRES, F. D., 1968. Tipos de mamíferos recentes no Museu Nacional do Rio de Janeiro. Arquivos do Museu Nacional 53: 161-191.

BEZERRA, A., 2012. Coleções Científicas de Mamíferos. I - Brasil. Boletim da Sociedade Brasileira de Mastozoologia (65): 19-25.

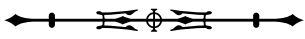


BEZERRA, A. M. \& S. BORDALLO, 2018. Neotropical felid specimens at the Museu Paraense Emilio Goeldi: species, distribution, and morphometric data. Papéis Avulsos de Zoologia 58: e20185833. DOI: https://doi.org/10.11606/1807-0205/2018.58.33

BORNHOLDT, R., K. HELGEN, K.-P. KOEPFLI, L. OLIVEIRA, M. LUCHERINI \& E. EIZIRIK, 2013. Taxonomic revision of the genus Galictis (Carnivora: Mustelidae): species delimitation, morphological diagnosis, and refined mapping of geographical distribution. Zoological Journal of the Linnean Society 167(3): 449-472. DOI: https://doi. org/10.1111/j.1096-3642.2012.00859.x

BOUBLI, J. P., A. DI FIORE, A. B. RYLANDS \& R. B. WALLACE, 2008. Lagothrix cana. The IUCN Red List of Threatened Species 2008: e.T39925A10288721. DOI: https://dx.doi.org/10.2305/IUCN. UK.2008.RLTS.T39925A10288721.en

BRANDÃO, M. V., R. V. ROSSI, T. B. F. SEMEDO \& S. E. PAVAN, 2015. Diagnose e distribuição geográfica dos marsupiais da Amazônia brasileira. In: A. C. MENDES-OLIVEIRA \& C. L. MIRANDA (Ed.): Pequenos mamíferos não-voadores da Amazônia brasileira: 95-148. Sociedade Brasileira de Mastozoologia, Rio de Janeiro.

BRANDÃO, M. V., G. S. T. GARBINO, T. B. F. SEMEDO, A. FEIJÓ, F. O. NASCIMENTO, H. FERNANDES-FERREIRA, R. V. ROSSI, J. DALPONTE \& A. P. CARMIGNOTTO, 2019. Mammals of Mato Grosso, Brazil: annotated species list and historical review. Mastozoología Neotropical 26(2): 263-307. DOI: https://doi. org/10.31687/saremMN.19.26.2.0.03

BRASIL, 2014. Ministério do Meio Ambiente. Portaria MMA n 43, de 31 de janeiro de 2014. Diário Oficial da União. Available at: https://mww.icmbio.gov.br/portal/images/stories/docs-plano-de-acaoARQUIVO/00-saiba-mais/03 - PORTARIA MMA N\%C2\%BA 43 DE_31_DE_JAN_DE_2014.̄̄pdf. Accessed on: 20 October $201 \overline{9}$.

BYRNE, H., A. B. RYLANDS, J. C. CARNEIRO, J. W. LYNCHALFARO, F. BERTUOL, M. N. F. DA SILVA, M. MESSIAS, C. P. GROVES, R. A. MITTERMEIER, I. FARIAS, T. HRBEK, F. SCHNEIDER, I. SAMPAIO \& J. P. BOUBLI, 2016. Phylogenetic relationships of the New World titi monkeys (Callicebus): fist appraisal of taxonomy based on molecular evidence. Frontiers in Zoology 13(10): 1-25. DOI: https://doi.org/10.1186/s12983-016-0142-4

CABALLERO, S., F. TRUJILLO, J. A. VIANNA, H. BARRIOSGARRIDO, M. G. MONTIEL, S. BELTRÁN-PEDREROS, M. MARMONTEL, M. C. SANTOS, M. ROSSI-SANTOS, F. R. SANTOS \& C. S. BAKER, 2007. Taxonomic status of the genus Sotalia: species Level ranking for "Tucuxi" (Sotalia fluviatilis) and "Costero" (Sotalia guianensis) dolphins. Marine Mammal Science 23(2): 358-386. DOI: https://doi.org/10.1111/.1748-7692.2007.00110.x

CABALLERO, S., J. JACKSON, A. A. MIGNUCCI-GIANNONI, H. BARRIOS-GARRIDO, S. BELTRÁN-PEDREROS, M. G. MONTIELVILLALOBOS, K. M. ROBERTSON \& C. S. BAKERA, 2008. Molecular systematics of South American dolphins Sotalia: Sister taxa determination and phylogenetic relationships, with insights into a multi-locus phylogeny of the Delphinidae. Molecular Phylogenetics and Evolution 46(1): 252-268. DOI: https://doi.org/10.1016/j.ympev.2007.10.015
CABALLERO, S., F. TRUJILLO, J. A. VIANNA, H. BARRIOSGARRIDO, M. G. MONTIEL, S. BELTRÁN-PEDREROS, M. MARMONTEL, M. C. O. SANTOS, M. R. ROSSI-SANTOS, F. R. SANTOS \& C. S. BAKER, 2010. Mitochondrial DNA diversity, differentiation and phylogeography of the South American riverine and coastal dolphins Sotalia fluviatilis and Sotalia guianensis. Latin American Journal of Aquatic Mammals 8(1-2): 69-79. DOI: http:// dx.doi.org/10.5597/lajam00155

CABRERA, A., 1958. Catalogo de los mamíferos de América del Sur. Revista del Museo Argentino de Ciencias Naturales "Bernardino Rivadavia", Ciencias Zoológicas 4(1): 1-307.

CERQueIRA, R. \& C. J. TRIBE, 2008. Genus Didelphis. In: A. L. GARDNER (Ed.): Mammals of the South America: vol. 1: Marsupials, Xenarthrans, Shrews, and Bats: 17-25. Chicago University Press, Chicago.

COMMITTEE ON TAXONOMY, 2017. List of marine mammal species and subspecies. Available at: www.marinemammalscience. org. Accessed on: 20 November 2019.

COSTA, L. P., Y. L. R. LEITE, S. L. MENDES \& A. D. DITCHFIELD, 2005. Mammal conservation in Brazil. Conservation Biology 19: 672-679. DOI: https://doi.org/10.1111/j.1523-1739.2005.00666.x

COZZUOL, M. A., C. L. ClOZATO, E. C. HOLANDA, F. H. G. RODRIGUES, S. N. IENOW, B. DE THOISY, R. A. F. REDONDO \& F. R. SANTOS, 2013. A new tapir from the Amazon. Journal of Mammalogy 94(6): 1331-1345. DOI: http://dx.doi.org/10.1644/12MAMM-A-169.1

DE VIVO, M., 1991. Taxonomia de Callithrix Erxleben, 1777 (Callitrichidae, Primates): 1-105. Fundação Biodiversitas, Belo Horizonte.

DE VIVO, M., A. P. CARMIGNOTTO, R. GREGORIN, E. HINGSTZAHER, G. E. IACK-XIMENES, M. MIRETZKI, A. R. PERCEQUILLO, M. M. ROLLO JR., R. V. ROSSI \& V. A. TADDEI, 2011. Checklist dos mamíferos do Estado de São Paulo, Brasil. Biota Neotropica 11(Supl. 1): 111-131. DOI: http://dx.doi.org/10.1590/S1676-06032011000500007

DE VIVO, M., L. F. SILVEIRA \& F. O. NASCIMENTO, 2014. Reflexões sobre coleções zoológicas, sua curadoria e a inserção dos Museus na estrutura universitária brasileira. Arquivos de Zoologia 45(esp.): 105113. DOI: https://doi.org/10.11606/issn.2176-7793.v45iespp105-113

DELSUC, F., G. C. GIBB, M. KUCH, G. BILLET, L. HAUTIER, J. SOUTHON, J.-M. ROUILLARD, J. C. FERNICOLA, S. F. VIZCAÍNO, R. D. E. MACPHEE \& H. N. POINAR, 2016. The phylogenetic affinities of the extinct glyptodonts. Current Biology 26(4): R155-R156. DOI: https://doi.org/10.1016/j.cub.2016.01.039

DELSUC, F., M. KUCH, G. C. GIBB, E. KARPINSKI, D. HACKENBERGER, P. SZPAK, J. G. MARTINÉZ, J. I. MEAD, H. G. MCDONALD, R. D. E. MACPHEE, G. BILLET, L. HAUTIER \& H. N. POINAR, 2019. Ancient mitogenomes reveal the evolutionary history and biogeography of sloths. Current Biology 29(12): 20312042. DOI: https://doi.org/10.1016/j.cub.2019.05.043

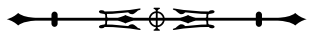


DUARTE, J. M. B. \& S. GONZÁLEZ, 2010. Neotropical Cervidology: biology and medicine of Latin American deer: 1-393. FUNEP, Jaboticabal.

DUARTE, J. M. B., U. PIOVEZAN, E. S. ZANETTI, H. G. C. RAMOS, L. M. TIEPOLO, A. VOGLIOTI, M. L. OLIVEIRA, L. F. RODRIGUES \& L. B. ALMEIDA, 2012. Avaliação do risco de extinção do cervo-do-Pantanal Blastocerus dichotomus Illiger, 1815, no Brasil. Biodiversidade Brasileira 2(3): 3-14.

DUNNUM, J. L., 2015. Family Caviidae G. Fischer, 1817. In: J. L. PATTON, U. F. J. PARDIÑAS \& G. D'ELÍA (Ed.): Mammals of the South America: vol. 2: Rodents: 690-726. Chicago University Press, Chicago.

EMIN-LIMA, R., A. L. F. RODRIGUES, M. E. M. SOUSA, D. L. ARCOVERDE, G. M. A. SANTOS, B. M. L. MARTINS, J. S. SILVA JUNIOR \& S. SICILIANO, 2010. Os mamíferos aquáticos associados aos manguezais da costa norte brasileira. In: L. M. PESSOA, W. C. TAVARES \& S. SICILIANO (Ed.): Mamíferos de restingas e manguezais do Brasil: 45-57. Sociedade Brasileira de Mastozoologia, Rio de Janeiro.

FARIA, M. B. \& F. R. MELO, 2017. Didelphis imperfecta, Didelphimorphia, Didelphidae (Mondolfi \& Pérez-Hernández, 1984): a new record in the Brazilian Amazon. Boletim da Sociedade Brasileira de Mastozoologia 79: 44-46.

FEIJÓ, A. \& A. LANGGUTH, 2013. Mamíferos de médio e grande porte do Nordeste do Brasil: distribuição e taxonomia, com descrição de novas espécies. Revista Nordestina de Biologia 22(1): 3-225.

FEIJÓ, A. \& P. CORDEIRO-ESTRELA, 2016. Taxonomic revision of the Dasypus kappleri complex, with revalidations of Dasypus pastasae (Thomas, 1901) and Dasypus beniensis Lönnberg, 1942 (Cingulara, Dasypodidae). Zootaxa 4170(2): 271-297. DOI: http:// dx.doi.org/10.11646/zootaxa.4170.2.3

FEIJÓ, A., B. D. PATTERSON \& P. CORDEIRO-ESTRELA, 2018. Taxonomic revision of the long-nosed armadillos, Genus Dasypus Linnaeus, 1758 (Mammalia, Cingulata). PLoS ONE 13(4): e0195084. DOI: https://doi.org/10.1371/journal. pone. 0195084

FEIJÓ, A., J. F. VILELA, J. CHENG, M. A. A. SCHETINO, R. T. F. COIMBRA, C. R. BONVICINO, F. R. SANTOS, B. D. PATTERSON \& P. CORDEIRO-ESTRELA, 2019. Phylogeny and molecular species delimitation of long-nosed armadillos (Dasypus: Cingulata) supports morphology-based taxonomy. Zoological Journal of the Linnean Society 186(3): 813-825. DOI: https:// doi.org/10.1093/zoolinnean/zly091

FERNANDEZ-DUQUE, E., M. K. CORLEY \& A. SPENCEAIZENBERG, 2013. Family Aotidae (night monkeys). In: R. A. MITTERMEIER, A. B. RYLANDS \& D. E. WILSON (Ed.): Handbook of the Mammals of the World: vol. 3: Primates: 414431. Lynx Edicions, Barcelona.
FISHER, R. D. \& C. A. LUDWIG, 2014. Catalog of type specimens of recent Mammals: Rodentia (Myomorpha, Anomaluromorpha, and Hystricomorpha in the National Museum of Natural History, Smithsonian Institution: 1-125. Smithsonian Institution Scholarly Press (Smithsonian Contributions to Zoology, 642), Washington. DOI: https://doi.org/10.5479/si.19436696.642

GARBINO, G. S. T., 2015. Defining genera of New World monkeys: the need for a critical view in a necessarily arbitrary task. International Journal of Primatology 36: 1049-1064. DOI: https:// doi.org/10.1007/s10764-015-9882-9

GARBINO, G. S. T. \& C. C. AQUINO, 2018. Evolutionary significance of the entepicondylar foramen of the humerus in New World monkeys (Platyrrhini). Journal of Mammalian Evolution 25: 141-151. DOI: https://doi.org/10.1007/s10914-016-9366-5

GARBINO, G. S. T. \& A. M. G. MARTINS-JUNIOR, 2018. Phenotypic evolution in marmoset and tamarin monkeys (Cebidae, Callitrichinae) and a revised genus-level classification. Molecular Phylogenetics and Evolution 118: 156-171. DOI: https://doi. org/10.1016/j.ympev.2017.10.002

GARDNER, A. L., 2005. Order Cingulata. In: D. E. WILSON \& D. M. REEDER (Ed.): Mammal species of the World: 3. ed.: 94-99. The Johns Hopkins University Press, Baltimore.

GARDNER, A. L., 2008. Order Pilosa. In: A. L. GARDNER (Ed.): Mammals of the South America: vol. 1: Marsupials, Xenarthrans, Shrews, and Bats: 157-177. Chicago University Press, Chicago.

GARDNER, A. L. \& M. DAGOSTO, 2008. Genus Metachirus. In: A. L. GARDNER (Ed.): Mammals of the South America: vol. 1: Marsupials, Xenarthrans, Shrews, and Bats: 35-39. Chicago University Press, Chicago.

GARDNER, A. L. \& V. L. NAPLES, 2008. Family Megalonychidae. In: A. L. GARDNER (Ed.): Mammals of the South America: vol. 1: Marsupials, Xenarthrans, Shrews, and Bats: 165-168. Chicago University Press, Chicago.

GIBB, G. C., F. L. CONDAMINE, M. KUCH, I. ENK, N. MORAESBARROS, M. SUPERINA, H. N. POINAR \& F. DELSUC, 2016. Shotgun mitogenomics provides a reference phylogenetic framework and timescale for living xenarthrans. Molecular Biology and Evolution 33(3): 621-642. DOI: https://doi.org/10.1093/molbev/ msv250

GLOBAL BIODIVERSITY INFORMATION FACILITY (GBIF), 2019. Mustela africana Desmarest, 1818. Available at: https://www.gbif. org/species/5219066. Accessed on: 6 February 2020.

GOELDI, E. A. \& G. HAGMANN, 1904. Prodromo de um catalogo critico, commentado da collecção de mammiferos no Museu do Pará (1894-1903). Boletim do Museu Goeldi de Historia Natural e Ethnographia 4(1-4): 1-122.

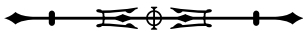


GONZÁlEZ, S., M. COSSE, F. G. BRAGA, A. R. VILA, M. L. MERINO, C. DELLAFIORE, J. L. CARTES, L. MAFFEI \& M. G. DIXON, 2010. Pampas deer Ozotoceros bezoarticus (Linnaeus 1758). In: J. M. B. DUARTE \& S. GONZÁLEZ(Ed.): Neotropical Cervidology: biology and medicine of Latin American deer: 119-132. FUNEP, Jaboticabal.

GOULDING, M., R. BARTHEM \& E. FERREIRA, 2003. The Smithsonian Atlas of the Amazon: 1-253. Smithsonian Books, Washington DC.

GREGORIN, R. \& M. DE VIVO, 2013. Revalidation of Saguinus ursula Hoffmannsegg (Primates: Cebidae: Callitrichinae). Zootaxa 3721(2): 172-182. DOI: http://dx.doi.org/10.11646/zootaxa.3721.2.4

GROVES, C. P., 2001. Primates Taxonomy: 1-350. Smithsonian Institution Press, Washington DC.

GRUBB, P., 2005a. Order Perissodactyla. In: D. E. WILSON \& D. M. REEDER (Ed.): Mammal species of the World: 3. ed.: 629-636. The Johns Hopkins University Press, Baltimore.

GRUBB, P., 2005b. Order Artiodactyla. In: D. E. WILSON \& D. M. REEDER (Ed.): Mammal species of the World: 3. ed.: 637-722. The Johns Hopkins University Press, Baltimore.

GUALDA-BARROS, J., F. O. NASCIMENTO \& M. K. AMARAL, 2012. A new species of Callicebus Thomas, 1903 (Primates, Pitheciidae) from the states of Mato Grosso and Pará, Brazil. Papéis Avulsos de Zoologia 52(23): 261-279. DOI: http://dx.doi. org/10.1590/S0031-10492012002300001

GUTIÉRREZ, E. E. \&J. MARINHO-FILHO, 2017. The mammalian faunas endemic to the Cerrado and the Caatinga. ZooKeys 644: 105-157. DOI: https://doi.org/10.3897/zookeys.644.10827

HALL, E. R., 1981. The mammals of North America: 2. ed.: 1-1181. John Wiley \& Sons, New York.

HERSHKOVITZ, P., 1983. Two new species of night monkeys, genus Aotus (Cebidae, Platyrrhini): a preliminary report on Aotus taxonomy. American Journal of Primatology 4(3): 209-243. DOI: https://doi. org/10.1002/ajp.1350040302

HERSHKOVITZ, P., 1985. A preliminary taxonomic review of the South American bearded saki monkeys genus Chiropotes (Cebidae, Platyrrhini), with the description of a new subspecies. Fieldiana Zoology 27: 1-46.

HERSHKOVITZ, P., 1987. The taxonomy of South American sakis, genus Pithecia (Cebidae, Platyrrhini): a preliminary report and critical review with the description of a new species and a new subspecies. American Journal of Primatology 12(4): 387-468. DOI: https://doi. org/10.1002/ajp.1350120402

HERSHKOVITZ, P., 1990. Titis, new world monkeys of the genus Callicebus (Cebidae, Platyrrhini): a preliminary taxonomic review. Fieldiana Zoology 55: 1-109.
HRBEK, T., V. M. F. DA SILVA, N. DUTRA, W. GRAVENA, A. R. MARTIN \& I. P. FARIAS, 2014. A new species of river dolphin from Brazil or: how little do we know our biodiversity. PloS One 9(1): e0083623. DOI: https://doi.org/10.1371/journal. pone.0083623

IACK-XIMENES, G. E., 1999. Sistemática da família Dasyproctidae Bonaparte, 1838 (Rodentia, Hystricognathi) no Brasil: 1-429. Masther Dissertation - Universidade de São Paulo, São Paulo.

INSTITUTO BRASILEIRO DE GEOGRAFIA E ESTATÍSTICA (IBGE), 2004. Mapa de vegetação do Brasil: 1 map, colored. Scale 1:5.000.000. IBGE, Rio de Janeiro.

INSTITUTO BRASILEIRO DE GEOGRAFIA E ESTATÍSTICA (IBGE), 2018. Área Territorial: área territorial brasileira. Available at: https://www.ibge.gov.br/cidades-e-estados/pa.html. Accessed in: 20 November 2019.

INSTITUTO CHICO MENDES DE CONSERVAÇÃO DA BIODIVERSIDADE (ICMBIO), 2018. Livro vermelho da fauna brasileira ameaçada de extinção: 1-4162. ICMBio/MMA, Brasília.

INTERNATIONAL UNION FOR CONSERVATION OF NATURE AND NATURAL RESOURCES (IUCN), 2019. The IUCN Red List of Threatened Species. Version 2019-2. Available at: https:// www.iucnredlist.org. Accessed on: 24 October 2019.

KITCHENER, A. C., C. BREITENMOSER-WURSTEN, E. EIZIRIK, A. GENTRY, L. WERDELIN, A. WILTING, N. YAMAGUCHI, A. V. ABRAMOV, P. CHRISTIANSEN, C. DRISCOLL, J. W. DUCKWORTH, W. JOHNSON, S.-J. LUO, E. MEIJAARD, P. O'DONOGHUE, J. SANDERSON, K. SEYMOUR, M. BRUFORD, C. GROVES, M. HOFFMANN, K. NOWELL, Z. TIMMONS \& S. TOBE, 2017. A revised taxonomy of the Felidae. The final report of the Cat Classification Task Force of the IUCN/ SSC Cat Specialist Group. Cat News, Special Issue 11: 3-79.

LAWRENCE, M. A., 1993. Catalog of recent mammal types in the American Museum of Natural History. Bulletin of the American Museum of Natural History 217: 1-200.

MARSH, L. K., 2014. A taxonomic revision of the Saki Monkeys, Pithecia Desmarest, 1804. Neotropical Primates 21(1): 1-163. DOI: https://doi.org/10.1896/044.021.0101

MARTÍNEZ-AGÜERO, M., S. FLORES-RAMÍREZ \& M. RUIZGARCÍA, 2006. First report of major histocompatibility complex class II loci from the Amazon pink river dolphin (genus Inia). Genetics and Molecular Research 5(3): 421-431.

MCBEE, K. \& R. J. BAKER, 1982. Dasypus novemcinctus. Mammalian Species 162: 1-9.

MEAD, J. G. \& R. L. BROWNELL JR., 2005. Order Cetacea. In: D. E. WILSON \& D. M. REEDER (Ed.): Mammal species of the World: 3. ed.: 723-743. Johns Hopkins University Press, Baltimore. 
MENDES-OLIVEIRA, A. C., I. H. V. V. LINKE, M. COELHO \& E. LIMA, 2011. Odocoileus virginianus, Zimmermann, 1780 (Mammalia: Cervidae): confirmed records and distribution extension in the northern Brazilian Amazon. Check List 7(6): 832-836. DOI: https:// doi.org/10.15560/7.6.832

MERCÊS, M. P., J. W. LYNCH-ALFARO, W. A. S. FERREIRA, M. L. HARADA \& J. S. SILVA JÚNIOR, 2015. Morphology and mitochondrial phylogenetics reveal that the Amazon River separates two eastern squirrel monkey species: Saimiri sciureus and S. collinsi. Molecular Phylogenetics and Evolution 82(Part B): 426-435. DOI: https://doi. org/10.1016/j.ympev.2014.09.020

MIRANDA, F. R., D. M. CASALI, F. A. PERINI, F. A. MACHADO \& F. R. SANTOS, 2017. Taxonomic review of the genus Cyclopes Gray, 1821 (Xenarthra: Pilosa), with the revalidation and description of new species. Zoological Journal of the Linnean Society 183(3): 687-721. DOI: https://doi.org/10.1093/zoolinnean/zl×079

MITTERMEIER, R. A., A. B. RYLANDS \& D. E. WILSON, 2013. Handbook of the Mammals of the World: vol. 3: Primates: 1-952. Lynx Edicions, Barcelona.

NAPIER, P. H., 1976. Catalogue of Primates in the British Museum (Natural History), Part 1: Families Callitrichidae and Cebidae: 1-122. British Museum (Natural History), London.

NASCIMENTO, F. O., 2014. On the morphological variation and taxonomy of the Geoffroy's cat Leopardus geoffroyi (d'Orbigny \& Gervais, 1844) (Carnivora, Felidae). Papéis Avulsos de Zoologia 54(11): 129-160. DOI: https://doi.org/10.1590/0031-1049.2014.54.11

NASCIMENTO, F. O. \& A. FEIJÓ, 2017. Taxonomic revision of the tigrina Leopardus tigrinus (Schreber, 1775) species group (Carnivora, Felidae). Papéis Avulsos de Zoologia 57(19): 231-264. DOI: http:// dx.doi.org/10.11606/0031-1049.2017.57.19

NEGRÕES, N., E. REVILLA, C. FONSECA, A. M. V. M. SOARES, A. T. A. JÁCOMO \& L. SILVEIRA, 2011. Private forest reserves can aid in preserving the community of medium and large-sized vertebrates in the Amazon arc of deforestation. Biodiversity Conservation 20: 505-518. DOI: http://dx.doi.org/10.1007/s10531-010-9961-3

OLIVEIRA, T. G., 2009. Notes on the distribution, status, and research priorities of little-known small carnivores in Brazil. Small Carnivore Conservation 41: 22-24.

OLIVEIRA, L. C., D. LORETTO, L. R. VIANA, J. S. SILVA-JR. \& G. FERNANDES, 2009. Primate community of the tropical rainforest of Saracá-Taqüera National Forest, Pará, Brazil. Brazilian Journal of Biology 69(4): 1091-1099. DOI: http://dx.doi.org/10.1590/S151969842009000500012

PAGLIA, A. P., G. A. B. FONSECA, A. B. RYLANDS, G. HERRMANN, L. M. S. AGUIAR, A. G. CHIARELLO, Y. L. R. LEITE, L. P. COSTA, S. SICILIANO, M. C. M. KIERULFF, S. L. MENDES, V. C. TAVARES, R. A. MITTERMEIER \& J. L. PATTON, 2012. Lista anotada dos mamíferos do Brasil: 2. ed.: 1-76. Conservação Internacional (Occasional Papers in Conservation Biology, 6), Belo Horizonte.
PATTON, J. L., 2015. Family Cuniculidae G. S. Miller and Gidley, 1918. In: J. L. PATTON, U. F. J. PARDIÑAS \& G. D'ELÍA (Ed.): Mammals of the South America: vol. 2: Rodents: 726-733. Chicago University Press, Chicago.

PATTON, J. L. \& M. N. F. SILVA, 2008. Genus Philander. In: A. L. GARDNER (Ed.): Mammals of the South America: vol. 1: Marsupials, Xenarthrans, Shrews, and Bats: 27-35. Chicago University Press, Chicago.

PATTON, J. L. \& L. H. EMMONS, 2015. Family Dasyproctidae Bonaparte, 1838. In: J. L. PATTON, U. F. J. PARDINAS \& G. D'ELÍA (Ed.): Mammals of the South America: vol. 2: Rodents: 733-762. Chicago University Press, Chicago.

PAYNTER JR., R. A. \& M. A. TRAYLOR JR., 1991. Ornithological Gazetteer of Brazil: 1-788. Harvard University, Massachusetts.

PERCEQUILLO, A. R., 2005. Coleções mastozoológicas. In: A. L. C. PRUDENTE (Ed.): Coleções brasileiras de vertebrados: estadoda-arte e perspectivas para os próximos dez anos: 27-31. Centro de Gestão e Estudos Estratégicos/Ciência, Tecnologia e Inovação, Belém.

PERCEQUILLO, A. R. \& R. GREGORIN, 2019. Mammalia. Catálogo Taxonômico da Fauna do Brasil. PNUD. Available at: http://fauna.jbrj. gov.br/fauna/faunadobrasil/64. Accessed on: 25 October 2019.

PERES, C. A., T. EMILIO, J. SCHIETTI, S. J. M. DESMOULIÈRE \& T. LEVI, 2016. Dispersal limitation induces long-term biomass collapse in overhunted Amazonian forests. Proceedings of the National Academy of Sciences of the United States of America 113(4): 892 897. DOI: https://doi.org/10.1073/pnas.1516525113

PIMENTA, F. E. \& J. S. SILVA JR., 2005. An update on the distribution of Primates of the Tapajós-Xingu interfluvium, Central Amazonia. Neotropical Primates 13(2): 25-30. DOI: https://doi. org/10.1896/1413-4705.13.2.23

PINTO, L. F., 2012. De Tucuruí a Belo Monte: a história avança mesmo? Boletim do Museu Paraense Emílio Goeldi, Ciências Humanas 7(3): 777-782. DOI: http://dx.doi.org/10.1590/S198181222012000300010

PINTO, O., 1945. Cinqüenta anos de investigação ornitológica: história das origens e do desenvolvimento da Coleção Ornitológica do Museu Paulista e de seu subsequente progresso no Departamento de Zoologia da Secretaria de Agricultura. Arquivos de Zoologia $4(8): 1-340$

PRESSLEE, S., G. I. SLATER, F. PUIOS, A. M. FORASIEPI, R. FISCHER, K. MOLLOY, M. MACKIE, J. V. OLSEN, A. KRAMARZ, M. TAGLIORETTI, F. SCAGLIA, M. LEZCANO, J. L. LANATA, J. SOUTHON, R. FERANEC, J. BLOCH, A. HAJDUK, F. M. MARTIN, R. S. GISMONDI, M. REGUERO, C. DE MUIZON, A GREENWOOD, B. T. CHAIT, K. PENKMAN, M. COLLINS \& R. D. E. MACPHEE, 2019. Palaeoproteomics resolves sloth relationships. Nature Ecology and Evolution 3: 1121-1130. DOI: https://doi. org/10.1038/s41559-019-0909-z

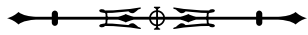


RAMÍREZ-CHAVES, H. E., H. L. ARANGO-GUERRA \& B. D. PATTERSON, 2014. Mustela africana (Carnivora: Mustelidae). Mammalian Species 46(917): 110-115. DOI: https://doi. org/10.1644/917.1

RODRIGUES, M. T., M. D. MARQUES, C. R. F. BRANDÃO \& J. L. FIGUEIREDO, 2000. Museu de Zoologia - preservação da história da fauna brasileira. In: A. A. ABREU (Ed.): Quantos anos faz o Brasil?: 71-77. Editora da Universidade de São Paulo, São Paulo.

ROSSI, R. V., 2000. Taxonomia de Mazama Rafinesque, 1817 do Brasil (Artiodactyla, Cervidae). Master Dissertation - Instituto de Biociências da Universidade de São Paulo, São Paulo.

ROSSI, R. V., C. L. MIRANDA \& T. B. F. SEMEDO. 2017. Rapid assessment of nonvolant mammals in seven sites in the northern State of Pará, Brazil: a forgotten part of the Guiana Region. Mammalia 81(5): 465-487. DOI: https://doi.org/10.1515/ mammalia-2016-0037

RUEDAS, L. A., 2017. A new species of cottontail rabbit (Lagomorpha: Leporidae: Sylvilagus) from Suriname, with comments on the taxonomy of allied taxa from Northern South America. Journal of Mammalogy 98(4): 1042-1059. DOI: https://doi.org/10.1093/ jmammal/gyx048

RUEDAS, L. A., S. M. SILVA, J. H. FRENCH, R. N. PLATT II, J. SALAZAR-BRAVO, J. M. MORA \& C. W. THOMPSON, 2017. A prolegomenon to the systematics of the South American cottontail rabbits (Mammalia, Lagomorpha, Leporidae: Sylvilagus): designation of a neotype for S. brasiliensis (Linnaeus, 1758), and restoration of S. andinus (Thomas, 1897) and S. tapetillus Thomas, 1913. Miscellaneous Publication Museum of Zoology (205): 1-67.

RUIZ-GARCÍA, M., A. CASTELLANOS, L. A. BERNAL, M. PINEDO-CASTRO, F. KASTON \& J. M. SHOSTELL, 2016. Mitogenomics of the mountain tapir (Tapirus pinchaque, Tapiridae, Perissodactyla, Mammalia) in Colombia and Ecuador: phylogeography and insights into the origin and systematics of the South American tapirs. Mammalian Biology 81(2): 163-175. DOI: https://doi.org/10.1016/j.mambio.2015.11.001

RYLANDS, A. B., H. SCHNEIDER, A. LANGGUTH, R. A. MITTERMEIER, C. P. GROVES \& E. RODRÍGUEZ-LUNA, 2000. An assessment of the diversity of New World primates. Neotropical Primates 8: 61-93.

SEGURA, V., F. J. PREVOSTI \& G. CASSINI, 2013. Cranial ontogeny in the Puma lineage, Puma concolor, Herpailurus yagouaroundi, and Acinonyx jubatus (Carnivora: Felidae): a three-dimensional geometric morphometric approach. Zoological Journal of the Linnean Society 169(1): 235-250. DOI: https://doi.org/10.1111/zoj.12047

SERRANO-VILLAVICENCIO, J. E., R. L. VENDRAMEL \& G. S. T. GARBINO, 2017. Species, subspecies, or color morphs? Reconsidering the taxonomy of Callicebus Thomas, 1903 in the Purus-Madeira interfluvium. Primates 58: 159-167. DOI: https:// doi.org/10.1007/s10329-016-0555-x
SERRANO-VILLAVICENCIO, J. E., C. M. HURTADO, R. L. VENDRAMEL \& F. O. NASCIMENTO, 2019. Reconsidering the taxonomy of the Pithecia irrorata species group (Primates: Pitheciidae). Journal of Mammalogy 100(1): 130-141. DOI: https:// doi.org/10.1093/jmammal/gyy167

SHOSHANI, J., 2005. Order Sirenia. In: D. E. WILSON \& D. M. REEDER (Ed.): Mammal species of the World: 3. ed.: 92-93. The Johns Hopkins University Press, Baltimore.

SICILIANO, S., V. H. VALIATI, R. EMIN-LIMA, A. F. COSTA, J. SARTOR, T. DORNELES, J. S. SILVA JR. \& L. R. OLIVEIRA, 2016. New genetic data extend the range of river dolphins Inia in the Amazon delta. Hydrobiologia 777(1): 255-269. DOI: https://doi. org/10.1007/S10750-016-2794-7

SILVA, S. M., A. TOWNSEND PETERSON, L. CARNEIRO, T. C. TORTOLA BURLAMAQUI, C. C. RIBAS, T. SOUSA-NEVES, L. S. MIRANDA, A. M. FERNANDES, F. M. D'HORTA, L. E. ARAUJO-SILVA, R. BATISTA, C. H. M. M. BANDEIRA, S. M. DANTAS, M. FERREIRA, D. M. MARTINS, J. OLIVEIRA, T. C. ROCHA, C. H. SARDELLI, G. THOM, P. S. REGO, M. P. SANTOS, F. SEQUEIRA, M. VALLINOTO \& A. ALEIXO, 2019. A dynamic continental moisture gradient drove Amazonian bird diversification. Science Advances 5(7): 1-10. DOI: https://doi. org/10.1126/sciadv.aat5752

SILVA, V. M. F. \& A. R. MARTIN, 2014. Family Iniidae (Amazon River Dolphins). In: D. WILSON \& R. A. MITTERMEIER (Ed.): Handbook of the Mammals of the World: vol. 4: Sea Mammals: 364-379. Lynx Edicions, Barcelona.

SILVA JR., J. S., 2001. Especiação nos macacos-prego e caiaras, gênero Cebus Erxleben, 1777 (Primates, Cebidae): 1-377. Doctoral Thesis - Universidade Federal do Rio de Janeiro, Rio de Janeiro.

SILVA JR., J. S., J. A. B. OHANA, C. R. SILVA, E. M. CARDOSO, A. A. AVELAR, V. F. SILVA \& L. S. SILVA, 2010. Mamíferos terrestres de médio e grande porte no litoral da Amazônia brasileira. In: L. M. PESSOA, W. C. TAVARES \& S. SICILIANO (Eds.): Mamíferos de restingas e manguezais do Brasil: 19-44. Sociedade Brasileira de Mastozoologia, Rio de Janeiro.

SILVA JR., J. S., W. M. B. FIGUEIREDO-READY \& S. F. FERRARI, 2013. Taxonomy and geographic distribution of the Pitheciidae. In: L. M. VEIGA, A. A. BARNETT, S. F. FERRARI \& M. A. NORCONK (Ed.): Evolutionary biology and conservation of Titis, Sakis and Uacaris: 31-42. Cambridge University Press, Cambridge.

SIMPSON, G. G., 1945. The principles of classification and a classification of mammals. Bulletin of the American Museum of Natural History 85: 1-350.

STEIN, B. R. \& J. L. PATTON, 2008. Genus Chironectes. In: A. L. GARDNER (Ed.): Mammals of the South America: vol. 1: Marsupials, Xenarthrans, Shrews, and Bats: 14-17. Chicago University Press, Chicago.

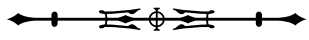


TETA, P., 2019. Geographic variation in quantitative skull traits in the genus Myoprocta Thomas, 1903 (Rodentia, Dasyproctidae) and its taxonomic implications. Mammalia 83(3): 212-218. DOI: https:// doi.org/10.1515/mammalia-2018-0022

TIEPOLO, L. M. \& W. M. TOMAS, 2011. Ordem Artiodactyla. In: N. R. REIS, A. L. PERACHI, W. A. PEDRO \& I. P. LIMA(Ed.): Mamíferos do Brasil: 2. ed.: 293-314. Edição do Autor, Londrina.

VANZOLINI, P. E., 1992. A supplement to the Ornithological Gazetteer of Brazil: 1-52. Museu de Zoologia, Universidade de São Paulo, São Paulo.

VIEIRA, C. O. C., 1944. Os símios do Estado de São Paulo. Papéis Avulsos do Departamento de Zoologia 4: 1-31.

VIEIRA, C. O. C., 1945. Sôbre uma coleção de mamíferos de Mato Grosso. Arquivos de Zoologia do Estado de São Paulo 4: 395-429.

VIEIRA, C. O. C., 1946. Carnívoros do Estado de São Paulo. Arquivos de Zoologia do Estado de São Paulo 5: 135-176.

VIEIRA, C. O. C., 1949. Xenarthros e marsupiais do Estado de São Paulo. Arquivos de Zoologia do Estado de São Paulo 7: 325-362.

VIEIRA, C. O. C., 1951. Notas sobre os mamíferos obtidos pela expedição do Instituto Butantã ao Rio das Mortes e Serra do Roncador. Papéis Avulsos do Departamento de Zoologia 10: 105-125.

VIEIRA, C. O. C., 1953a. Roedores e lagomorfos do Estado de São Paulo. Arquivos de Zoologia do Estado de São Paulo 8: 129-168.

VIEIRA, C. O. C., 1953b. Sobre uma coleção de mamíferos do Estado de Alagoas. Arquivos de Zoologia do Estado de São Paulo 8: 209-224.

VIEIRA, C. O. C., 1957. Sôbre mamíferos do Estado do Maranhão. Papéis Avulsos do Departamento de Zoologia 13: 125-132.

VOSS, R. S., 2015. Superfamily Erethizontoidea. In: J. L. PATTON, U. F. J. PARDIÑAS \& G. D'ELÍA (Ed.): Mammals of the South America: vol. 2: Rodents: 786-805. Chicago University Press, Chicago.

VOSS, R. S., D. P. LUNDE \& N. B. SIMMONS, 2001. The mammals of Paracou, French Guiana, a Neotropical lowland rainforest fauna. Part 2, Nonvolant species. Bulletin of the American Museum of Natural History (263): 1-236.
VOSS, R. S., K. M. HELGEN \& S. A. JANSA, 2014. Extraordinary claims require extraordinary evidence: a comment on Cozzuol et al. (2013). Journal of Mammalogy 95(4): 893-898. DOI: https:// doi.org/10.1644/14-MAMM-A-054

VOSS, R. S., J. F. DÍAZ-NIETO, S. A. JANSA \& R. ANGERMANN, 2018. A revision of Philander (Marsupialia, Didelphidae). Part 1, P. quica, $P$. canus, and a new species from Amazonia. American Museum Novitates (3891): 1-70. DOI: https://doi.org/10.1206/3891.1

VOSS, R. S., D. W. FLECK \& S. A. JANSA, 2019. Mammalian diversity and Matses ethnomammalogy in Amazonian Peru. Part 3: Marsupials (Didelphimorphia). Bulletin of the American Museum of Natural History (432): 1-87. DOI: https://doi.org/10.1206/0003-0090.432.1.1

WETZEL, R. M., 1975. The species of Tamandua Gray (Edentata, Myrmecophagidae). Proceedings of the Biological Society of Washington 88: 95-112.

WETZEL, R. M., 1985. The identification and distribution of Recent Xenarthra (=Edentata). In: G. G. MONTGOMERY (Ed.): The evolution and ecology of armadillos, sloths, and vermilinguas: 5-21. Smithsonian Institution Press, Washington DC.

WETZEL, R. M. \& E. MONDOLFI, 1979. The subgenera and species of long-nosed armadillos, genus Dasypus L. In: J. F. EISENBERG (Ed.): Vertebrate Ecology in the Northern Neotropics: 43-63. Smithsonian Institution Press, Washington DC.

WETZEL, R. M. \& F. D. ÁVILA-PIRES, 1980. Identification and distribution of the recent sloths of Brazil (Edentata). Revista Brasileira de Biologia 40: 831-836.

WETZEL, R. M., A. L. GARDNER, K. H. REDFORD \& J. F. EISENBERG, 2008. Order Cingulata. In: A. L. GARDNER (Ed.): Mammals of the South America: vol. 1: Marsupials, Xenarthrans, Shrews, and Bats: 128-157. Chicago University Press, Chicago.

WOZENCRAFT, W. C., 2005. Order Carnivora. In: D. E. WILSON \& D. R. REEDER (Ed.): Mammal species of the world: a taxonomic and geographic reference: 3. ed.: 532-628. Johns Hopkins University Press, Baltimore.

YENSEN, E. \& T. TARIFA, 2003a. Galictis vittata. Mammalian Species 727: 1-8.

YENSEN, E. \& T. TARIFA, 2003b. Galictis cuja. Mammalian Species 728: 1-8.

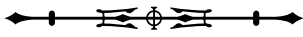


BRAZIL

\section{Pará state}

1. Igarapé Taperebá, Ilha de Marajó. $00^{\circ} 13^{\prime} \mathrm{S}, 50^{\circ} 33^{\prime} \mathrm{W}$

2. Alegre, $15 \mathrm{~km} \mathrm{NE} \mathrm{Marapanim.} 00^{\circ} 36^{\prime} \mathrm{S}, 47^{\circ} 40^{\prime} \mathrm{W}$

3. Maracanã, llha de Maiandeua, Algodoal. $00^{\circ} 36^{\prime} \mathrm{S}, 47^{\circ} 35^{\prime} \mathrm{W}$

4. Marapanim, Marudá. $00^{\circ} 42^{\prime} \mathrm{S}, 47^{\circ} 42^{\prime} \mathrm{W}$

5. Soure, Fazenda Teso, Ilha de Marajó. $00^{\circ} 44^{\prime}$ S, $48^{\circ} 31^{\prime}$ W

6. Anajás. $00^{\circ} 59^{\prime} \mathrm{S}, 49^{\circ} 57^{\prime} \mathrm{W}$

7. Ilha de Marajó. $01^{\circ} 00^{\prime} \mathrm{S}, 49^{\circ} 30^{\prime} \mathrm{W}$

8. Bragança. $01^{\circ} 03^{\prime} \mathrm{S}, 46^{\circ} 46^{\prime} \mathrm{W}$

9. Cachoeira da Porteira, Rio Nhamundá. $01^{\circ} 05^{\prime} \mathrm{S}, 57^{\circ} 02^{\prime} \mathrm{W}$

10. Igarapé Jaramacaru. $01^{\circ} 09^{\prime} \mathrm{S}, 55^{\circ} 54^{\prime} \mathrm{W}$

11. As Pedras, Rio Cuminá-Miri. $01^{\circ} 17^{\prime} \mathrm{S}, 55^{\circ} 52^{\prime} \mathrm{W}$

12. Lago Jacaré, Rio Trombetas. $01^{\circ} 18^{\prime} \mathrm{S}, 56^{\circ} 17^{\prime} \mathrm{W}$

13. Icoaraci. $01^{\circ} 18^{\prime} \mathrm{S}, 48^{\circ} 28^{\prime} \mathrm{W}$

14. Rio Cuminá-Miri (mouth). $01^{\circ} 18^{\prime} \mathrm{S}, 55^{\circ} 56^{\prime} \mathrm{W}$

15. Reserva Biológica do Rio Trombetas. $01^{\circ} 20^{\prime} \mathrm{S}, 56^{\circ} 45^{\prime} \mathrm{W}$

16. Ananindeua. $01^{\circ} 22^{\prime} \mathrm{S}, 48^{\circ} 23^{\prime} \mathrm{W}$

17. Ponta de Pedras, llha de Marajó. $01^{\circ} 23^{\prime}$ S, $48^{\circ} 52^{\prime} \mathrm{W}$

18. Belém. $01^{\circ} 26^{\prime} \mathrm{S}, 48^{\circ} 29^{\prime} \mathrm{W}$

19. São Miguel do Guamá. $01^{\circ} 37^{\prime}$ S, $47^{\circ} 27^{\prime}$ W

20. Oriximiná. $01^{\circ} 46^{\prime} \mathrm{S}, 55^{\circ} 51^{\prime} \mathrm{W}$

21. Lago Sapucuá, Rio Trombetas. $01^{\circ} 46^{\prime} \mathrm{S}, 56^{\circ} 03^{\prime} \mathrm{W}$

22. Curuá, Lago Cuiteuá, Rio Amazonas. $01^{\circ} 49^{\prime} \mathrm{S}, 54^{\circ} 58^{\prime} \mathrm{W}$

23. Paraná do Samaúma, Rio Tocantins. $01^{\circ} 51^{\prime} \mathrm{S}, 49^{\circ} 00^{\prime} \mathrm{W}$

24. Lago Paru, Rio Trombetas. $01^{\circ} 53^{\prime} \mathrm{S}, 55^{\circ} 48^{\prime} \mathrm{W}$

25. Igarapé Bravo, Rio Amazonas. $01^{\circ} 54^{\prime} \mathrm{S}, 55^{\circ} 10^{\prime} \mathrm{W}$

26. Óbidos. $01^{\circ} 55, \mathrm{~S}, 55^{\circ} 31, \mathrm{~W}$

27. Igarapé Piaba. $02^{\circ} 00^{\prime} \mathrm{S}, 55^{\circ} 20^{\prime} \mathrm{W}$

28. Boiuçu. $02^{\circ} 05^{\prime} \mathrm{S}, 55^{\circ} 14^{\prime} \mathrm{W}$

29. Arimateua, Rio Tocantins. $02^{\circ} 06^{\prime} \mathrm{S}, 49^{\circ} 11^{\prime} \mathrm{W}$

30. Paissandu, Igarapé Bom Jardim. $02^{\circ} 06^{\prime} \mathrm{S}, 56^{\circ} 18^{\prime} \mathrm{W}$

31. BR-010, $\mathrm{km} 87-94.02^{\circ} 06^{\prime} \mathrm{S}, 47^{\circ} 34^{\prime} \mathrm{W}$

32. BR-010, km 92 / São Domingos do Capim, BR-10, km 92. 0209' S, 47³5' W

33. Capim, Rodovia BR-14, km 93/Capim, BR-010, km 93/Capim, BR-010, km 94/Capim. 02 '10' S, 47³5' W

34. Faro. $02^{\circ} 10^{\prime} \mathrm{S}, 56^{\circ} 44^{\prime} \mathrm{W}$

35. Jaguara. $02^{\circ} 12^{\prime} \mathrm{S}, 54^{\circ} 24^{\prime} \mathrm{W}$

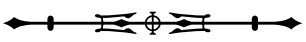


36. Cametá, Rio Tocantins. $02^{\circ} 15^{\prime} \mathrm{S}, 49^{\circ} 30^{\prime} \mathrm{W}$

37. Curral Grande. $02^{\circ} 20^{\prime} \mathrm{S}, 54^{\circ} 07^{\prime} \mathrm{W}$

38. Rio Curuá (mouth). $02^{\circ} 22^{\prime} \mathrm{S}, 54^{\circ} 05^{\prime} \mathrm{W}$

39. Rio Curuá-Una (mouth). $02^{\circ} 23^{\prime} \mathrm{S}, 54^{\circ} 04^{\prime} \mathrm{W}$

40. Rio Tapajós. $02^{\circ} 24^{\prime} \mathrm{S}, 54^{\circ} 41^{\prime} \mathrm{W}$

41. Cacaoal Grande. $02^{\circ} 24^{\prime} \mathrm{S}, 54^{\circ} 25^{\prime} \mathrm{W}$

42. Santarém. $02^{\circ} 25^{\prime} \mathrm{S}, 54^{\circ} 48^{\prime} \mathrm{W}$

43. Santarém, Fazenda Mararu, Rio Tapajós. $02^{\circ} 26^{\prime} \mathrm{S}, 54^{\circ} 42^{\prime} \mathrm{W}$

44. Santarém, Alter do Chão. $02^{\circ} 32^{\prime}$ S, 54 57' W

45. Santarém, Fazenda Marucu. $02^{\circ} 32^{\prime} \mathrm{S}, 54^{\circ} 55^{\prime} \mathrm{W}$

46. Taperinha. $02^{\circ} 32^{\prime} \mathrm{S}, 54^{\circ} 18^{\prime} \mathrm{W}$

47. Os Patos. $02^{\circ} 32^{\prime} \mathrm{S}, 54^{\circ} 18^{\prime} \mathrm{W}$

48. Caxiricatuba, Rio Tapajós. $02^{\circ} 36^{\prime} \mathrm{S}, 54^{\circ} 56^{\prime} \mathrm{W}$

49. Aruã, Rio Arapiuns. $02^{\circ} 39^{\prime} \mathrm{S}, 55^{\circ} 40^{\prime} \mathrm{W}$

50. Rio Curuá do Sul (mouth). $02^{\circ} 39^{\prime} \mathrm{S}, 54^{\circ} 10^{\prime} \mathrm{W}$

51. Bom Jardim, Rio Amazonas. $02^{\circ} 46^{\prime} \mathrm{S}, 54^{\circ} 21^{\prime} \mathrm{W}$

52. Santo Antônio, Rio Tocantins. $02^{\circ} 49^{\prime} \mathrm{S}$, $49^{\circ} 40^{\prime} \mathrm{W}$

53. Boim. $02^{\circ} 49^{\prime} \mathrm{S}, 55^{\circ} 10^{\prime} \mathrm{W}$

54. Tapaiúna, Rio Tapajós. $02^{\circ} 53^{\prime} \mathrm{S}, 55^{\circ} 04^{\prime} \mathrm{W}$

55. Piquiatuba, Rio Tapajós. $03^{\circ} 02^{\prime} \mathrm{S}, 55^{\circ} 07^{\prime} \mathrm{W}$

56. Tauari, Rio Tapajós. $03^{\circ} 05^{\prime} \mathrm{S}, 5^{\circ} 06^{\prime} \mathrm{W}$

57. Pau de Letra, Rio Tapajós. $03^{\circ} 08^{\prime} \mathrm{S}, 55^{\circ} 14^{\prime} \mathrm{W}$

58. Urucurituba, Rio Tapajós. $03^{\circ} 12^{\prime} \mathrm{S}, 55^{\circ} 30^{\prime} \mathrm{W}$

59. Itapoama, Rio Tapajós. $03^{\circ} 20^{\prime} \mathrm{S}, 55^{\circ} 12^{\prime} \mathrm{W}$

60. Ilha do Limão, Rio Xingu. $03^{\circ} 24^{\prime} \mathrm{S}, 51^{\circ} 49^{\prime} \mathrm{W}$

61. Juruá, Rio Xingu. $03^{\circ} 24^{\prime} \mathrm{S}, 51^{\circ} 53^{\prime} \mathrm{W}$

62. Aveiro. $03^{\circ} 35^{\prime} \mathrm{S}, 55^{\circ} 19^{\prime} \mathrm{W}$

63. Rio Bacajá (mouth). $03^{\circ} 36^{\prime} \mathrm{S}, 51^{\circ} 54^{\prime} \mathrm{W}$

64. Samaúma. $03^{\circ} 36^{\prime} \mathrm{S}, 55^{\circ} 35^{\prime} \mathrm{W}$

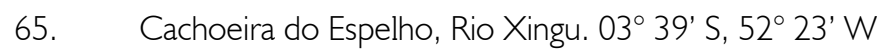

66. Cachoeira do Escalaço, Rio Xingu. $03^{\circ} 42^{\prime} \mathrm{S}, 52^{\circ} 21^{\prime} \mathrm{W}$

67. Terra Santa, Rio Jamari. $03^{\circ} 43^{\prime} \mathrm{S}, 56^{\circ} 37^{\prime} \mathrm{W}$

68. Santa Rosa, Illha de Urucurituba. $03^{\circ} 45^{\prime} \mathrm{S}, 55^{\circ} 30^{\prime} \mathrm{W}$

69. Tavio, Rio Tapajós. $03^{\circ} 47^{\prime} \mathrm{S}, 55^{\circ} 27^{\prime} \mathrm{W}$

70. Fordlândia / Fordlândia, Fazenda Nova. $03^{\circ} 47^{\prime}$ S, 55 $28^{\circ} \mathrm{W}$

71. Sumaúma, Rio Tapajós. $03^{\circ} 48^{\prime} \mathrm{S}, 55^{\circ} 32^{\prime} \mathrm{W}$

72. Braślia Legal, Rio Tapajós. $03^{\circ} 49^{\prime} \mathrm{S}, 55^{\circ} 36^{\prime} \mathrm{W}$

73. Arara, Rio Tapajós. $03^{\circ} 52^{\prime} \mathrm{S}, 5^{\circ} 35^{\prime} \mathrm{W}$ 
Appendix 1.

(Conclusion)

74. Largo do Souza, Rio Iriri. $03^{\circ} 54^{\prime} \mathrm{S}, 52^{\circ} 40^{\prime} \mathrm{W}$

75. Pedreira, Rio Tapajós. $04^{\circ} 03^{\prime} \mathrm{S}, 55^{\circ} 36^{\prime} \mathrm{W}$

76. Barreira, Rio Tapajós. $04^{\circ} 04^{\prime} \mathrm{S}, 55^{\circ} 45^{\prime} \mathrm{W}$

77. Monte Cristo, Rio Tapajós. $04^{\circ} 04^{\prime} \mathrm{S}, 55^{\circ} 39^{\prime} \mathrm{W}$

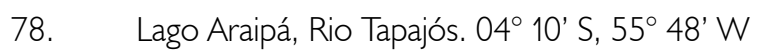

79. Vila Bravo, Rio Tocantins. $04^{\circ} 15^{\prime} \mathrm{S}, 49^{\circ} 32^{\prime} \mathrm{W}$

80. Transamazônica km 46 / Transamazônica km 50, near Itaituba / Transamazônica km 75, near Itaituba /

Transamazônica km 62, near Itaituba / Transamazônica km 58, near Itaituba / Transamazônica km 80, near Itaituba / Transamazônica km 100 / Itaituba / Itaituba, Parque Nacional da Amazônia / Parque Nacional da Amazônia / Parque Nacional da Amazônia, Rio Tapajós / Transamazônica km 66, Parque Nacional da Amazônia / Parque Nacional da

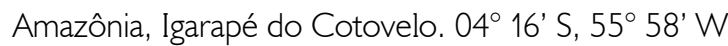

81. Transamazônica km 15, near Itaituba. $04^{\circ} 17^{\prime} \mathrm{S}, 56^{\circ}$ 05' W

82. Rio Pucuruí, tributary of Rio Tocantins. $04^{\circ} 25^{\prime} \mathrm{S}, 49^{\circ} 55^{\prime} \mathrm{W}$

83. Remansinho, Rio Tocantins. $04^{\circ} 25^{\prime} \mathrm{S}, 49^{\circ} 34^{\prime} \mathrm{W}$

84. Barreirinha, Rio Tapajós. $04^{\circ} 25^{\prime} \mathrm{S}, 56^{\circ} 13^{\prime} \mathrm{W}$

85. São Luís, Rio Tapajós. $04^{\circ} 26^{\prime} \mathrm{S}, 56^{\circ} 14^{\prime} \mathrm{W}$

86. Morro da Terra Preta, Transamazônica km 60, near Itaituba. $04^{\circ} 32^{\prime} \mathrm{S}, 56^{\circ} 20^{\prime} \mathrm{W}$

87. Pimental. $04^{\circ} 36^{\prime} \mathrm{S}, 56^{\circ} 15^{\prime} \mathrm{W}$

88. Uruá, Rio Tapajós / Parque Nacional da Amazônia, Uruá / Parque Nacional da Amazônia, Uruá, km 65.

$04^{\circ} 37^{\prime} \mathrm{S}, 56^{\circ} 15^{\prime} \mathrm{W}$

89. Igarapé São José, near Itaituba. $04^{\circ} 38^{\prime} \mathrm{S}, 56^{\circ} 11^{\prime} \mathrm{W}$

90. Ilha de Nova Olinda, Rio Tapajós. $04^{\circ} 38^{\prime} \mathrm{S}, 56^{\circ} 17^{\prime} \mathrm{W}$

91. Boa Fé, Parque Nacional do Tapajós. $04^{\circ} 38^{\prime} \mathrm{S}, 56^{\circ} 11^{\prime} \mathrm{W}$

92. Bagagem, Rio Tocantins. $04^{\circ} 45^{\prime} \mathrm{S}, 49^{\circ} 26^{\prime} \mathrm{W}$

93. Igarapé Águas da Saúde, Rio Tocantins. $04^{\circ} 45^{\prime} \mathrm{S}, 49^{\circ} 26^{\prime} \mathrm{W}$

94. Puraquecuara, Rio Tocantins. $04^{\circ} 54^{\prime} \mathrm{S}, 49^{\circ} 25^{\prime} \mathrm{W}$

95. Itupiranga, Rio Tocantins. $05^{\circ} 09^{\prime} \mathrm{S}, 49^{\circ} 20^{\prime} \mathrm{W}$

96. Il Iha de Santa Helena, Rio Pará. $05^{\circ} 13^{\prime}$ S, 56 $16^{\circ}$ ' W

97. Canaã dos Carajás. $06^{\circ} 29^{\prime}$ S, $49^{\circ} 52^{\prime} \mathrm{W}$

98. Gorotire. $07^{\circ} 47^{\prime} \mathrm{S}, 51^{\circ} 08^{\prime} \mathrm{W}$

99. Cachimbo / Cachimbo, Formiga. $08^{\circ} 57^{\prime} \mathrm{S}, 54^{\circ} 54^{\prime} \mathrm{W}$

100. Serra do Cachimbo. $09^{\circ} 00^{\prime} \mathrm{S}, 55^{\circ} 15^{\prime} \mathrm{W}$

101. Santana do Araguaia, Fazenda Fartura. $09^{\circ} 38^{\prime} \mathrm{S}, 50^{\circ} 26^{\prime} \mathrm{W}$

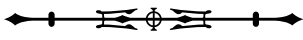


